\title{
Progress, problems and patterns in the biogeography of reef corals and other tropical marine organisms*
}

\author{
Brian R. Rosen \\ Department of Palaeontology, British Museum (Natural History); Cromwell Road, \\ London SW7 5BD, UK
}

\begin{abstract}
This first part of this paper summarizes the descriptive biogeography of reef corals, with mention of other tropical marine organisms, in terms of present-day latitudinal and longitudinal patterns, and stratigraphical patterns (mostly Cainozoic). Present-day generic distributions are well known but species distributions may be a much more complex mosaic than is generally recognized. In particular, further work is needed on geographical population dynamics, possible disjunctions and larval biology. Knowledge of stratigraphical history is currently hindered by insufficient systematic work on Cainozoic corals. The second part reviews current theories for explaining the distribution of reef corals. Biogeographical ideas can be conveniently discussed in terms of a biogeographical system in which there are three groups of processes: maintenance, distributional change and origination. These are not necessarily mutually incompatible. There is considerable confusion generated by different meanings of "dispersal" but they can be clarified with respect to this scheme. Maintenance theories are broadly ecological, and, for reef corals, more work is needed to test ideas about distributional dynamics, thermal ecophysiology and effects of geographical differences in sea water nutrients. Theories of origination and distributional change are largely historical. There are at least thirteen current historical theories for reef corals. These are discussed with respect to the limited amount of empirical analysis that is available. This points to the importance of geotectonic events, and possibly glacio-eustasy, both of which appear to have had considerable influence in the Miocene. Newer ideas reflect a search for testable alternatives to the older idea of an Indo-West Pacific centre of origin. In particular, hypotheses about vicariance amongst oceanic islands, early Cainozoic isolation of Pacific basin regions, late Cainozoic convergence of Indo-Pacific faunas, and vicariance due to a possible land barrier between S. E. Asia and Australia all merit further testing, especially by endemicity analysis, cladistic methods and speciation rate studies.
\end{abstract}

\section{INTRODUCTION}

\section{Context}

It has long been known that the basic features of reef coral distribution correspond broadly to those of numerous other reef-associated and tropical marine organisms, especially mangroves, sea grasses, and many larger benthonic foraminiferan, algal, molluscan, echinoderm, decapod crustacean, and fish groups. A reasonable inference from this distributional similarity is that these organisms share a similar biogeographical history. It is for this reason that a paper on reef corals might be of interest in a wider context such as this botanical symposium.

\footnotetext{
- Paper presented at the XIV International Botanical Congress (Berlin, 24 July-1 August, 1987), Symposium 6-15, "Biogeography of marine benthic algae".
} 
Reef corals (or more strictly, zo ox a n the lla te corals (Rosen, 1981; Schuhmacher \& Zibrowius, 1985) are not only hosts for zooxanthellae (endodermal, symbiotic dinoflagellate algae), but often also for endolithic, filamentous green algae. In effect, zooxanthellate corals can be regarded as living greenhouses or photosynthetic animals. Moreover, their colonial forms are modular in construction and have external morphologies and clonal life histories like many higher plants (Rosen, 1986; Dauget 1986); they are mostly attached to the substrate, and occupy a broadly similar habitat in tropical waters to brown algae in temperate waters (Stephenson \& Stephenson, 1949; Taylor, 1968). Even leaving aside the Symposium organizers' reasons for inviting a contribution on corals, these plant-like aspects of coral life-style make a contribution on corals not entirely incongruous in a botanical Symposium.

\section{Biogeography: towards an integrated approach}

It has always been easier in biogeography to devise explanations than to test them. There can be few subjects that have offered so much scope for so many people to speculate at such length on so little evidence. Whole schools have grown up around favoured groups of theories or methods, often with little real exchange between them. Moreover, there can be few subjects that demonstrate so well the problems generated by confusion between pattern and process.

Four points might help to clarify what biogeographers are trying to do and how they might achieve their aims (summarized from Rosen, 1988a):

(1) It is useful to distinguish between (a) "pure" aims of biogeography, which include explanations of distributions, and investigation of the processes concerned, and (b) "applied" aims, in which distributions are used as a means of discovering something else, like reconstructing earth history. These two aims are not always clearly distinguished, probably because too little is known about the feedback between biological and geological processes. (The present paper falls into the "pure" category.)

(2) Biogeography has been widely criticized as lacking in scientific rigour, and a strong case made for a more analytical, hypothesis-testing approach. Although this is also the view taken here, I do not think it possible, for biogeographers at least, to adhere strictly to hypothetico-deductive methods alone. Induction is also indispensable and in contrast with the views of systematists and biogeographers who have adopted a "Popperian" standpoint, it should not be regarded as an unrigorous, uncritical amassing of facts, but as a basic part of intelligent pattern-seeking and modelling.

(3) We can conceive of a model of the biog e o graphical system, consisting of all the processes that shape distributions. Table 1 (from Rosen, 1988a) summarizes the main ideas that exist in the literature about these biogeographical processes and represents a first step towards modelling the biogeographical system. It includes numerous concepts and processes not all of which are compatible with each other. Compatibility is in part a function of the different levels within the system at which different processes operate, especially their temporal and spatial scales. The ideas in Table 1 also vary in their acceptance amongst biogeographers, but in time, it should become clearer which are most relevant, and easier to develop more quantifiable, self-consistent and integrated biogeographical models. At the moment, the table should be seen more as a summary of 
Table 1. The biogeographical system, grouped into three sets of concepts and processes. This is a list of the main ideas that biogeographical authors have variously suggested for explaining distributions. The most likely causes of distributions are probably due to a compatible combination of maintenance, distributional change and origination ideas, though not all the ideas shown are compatible with each other. Inclusion of a particular idea is not meant to signify that it is advocated here, nor that it has a consensus of acceptance amongst biogeographers (After Rosen, 1988a). + these headings are introduced for palaeobiogeographical studies; TECO = tectonic, eustatic, climatic and oceanographic

\begin{tabular}{ccc}
\hline Concepts and assumed processes & Ecological biogeography' & 'Historical biogeography' \\
or & or \\
short-term processes & or & long-term processes \\
or & contemporaneous $_{\text {processes }^{+}}$ & antecedent processes $^{+}$ \\
& \\
\hline
\end{tabular}

\section{Maintenance}

(1) Dispersion

(2) Geoecology

(3) Equilibrium theory and island biogeography

(4) Barriers

(5) Geoecological assemblages

(6) Provinces and provinciality

Distributional change

(1) Range expansion

(2) Jump dispersal

(3) Equilibrium theory and island biogeography

(4) Earth history (= TECO events and changing palaeogeography)

(5) Environmental tracking as a response to:

5.1. ecological change

5.2. the effect of earth history on ecological change

(6) Adaptation of a taxon to different conditions

Originations

(1) Empirical phylogenetic biogeography

(2) Vicariance as a response to:

2.1. earth history

2.2. ecological change or the effect of earth history on ecological change

(3) Fringe isolation as a response to:

3.1. ecological change

3.2. the effect of earth history on ecological change

(4) Jump dispersal

(5) Centres of origin (in part)

(6) Geoecology through time 
the various general ideas that have been put forward in the history of the subject, and as an agenda for future refinement.

(4) Instead of the customary simple grouping of processes within the biogeographical system under two headings of historical and ecological, Table 1 shows a threepart division of processes into maintenance, distributional change and origination. Maintenance processes are those by which a species maintains its existence in the area in which it occurs at any one time, together with the environmental factors that affect its existence. Maintenance is therefore primarily ecological. Processes of distributional change are those that cause the range of a taxon to change through time, and because they can (theoretically) occur on any time scale, they are both ecological and historical. Origination processes correspond to speciations (and, by extension, extinctions) and are historical. This three-part scheme is not a categoric statement of what actually happens to species, but rather a summary of possibilities. While it is reasonable to suppose that a species came into existence in one particular part of the world rather than globally, its origin was not necessarily a response to geographical factors. Similarly, species have not necessarily changed their distributions during their stratigraphical duration; they may have remained exactly where they first occurred.

\section{Observations and patterns}

Before treating distributions of reef corals and ideas about the origin of these distributions, it is necessary to discuss briefly the nature of patterns. This is summarized from Rosen (1988a).

Patterns are derived from the raw data of observations, either subjectively, or through some kind of formal, usually mathematical, treatment. Formal pattern extraction may be relatively simple, like a numerical total or average, or sophisticated and highly specific to a particular question, as with area cladograms in cladistic biogeography. Although ideas about the origin of a particular distribution are sometimes derived directly from raw observations, it is more common to base them on patterns derived from processing distributional data. Ideas themselves range from informal suggestions to more detailed and precise models and strict hypotheses in an intergradational spectrum of levels of understanding. These ideas in turn affect observations and choice of methods of pattern extraction. It is unlikely that observations and methods are ever completely free from assumptions of process, especially in historical biogeography.

There is a dilemma presented by this cycle. Ideally, one would begin an account of distributions as objectively as possibly with "the facts", but this would result in lengthy and undigestible data lists, and even these would contain subjective information (e.g. in the choice of generic names, or designation of sample areas). On the other hand, any kind of extraction or generalization from such data amounts to pattern-seeking and this will be implicitly biased towards particular ideas about process from the outset. For instance, the use of isopangeneric contours for expressing geographical diversity has different implications from the simple presentation of diversity totals at each sample locality point (Rosen, 1984; and see below). As there is little realistic alternative but to begin at some level of generalization (i.e. a pattern), I have aimed to keep this as simple as possible. More complex patterns generally arise from investigations of more specific questions, examples of which are mentioned later in the paper. 


\section{DESCRIPTIVE BIOGEOGRAPHY OF REEF CORALS}

\section{Introduction}

Data on the distribution of modern reef coral genera have been readily available for a long time, largely through the work of John Wells (especially the Indopacific summary in Wells, 1954). Although various authors have supplemented the details, and he himself updates them regularly in unpublished versions, these changes are primarily of interest to coral workers themselves and to marine specialists of particular regions, and do not fundamentally alter the picture as represented here. This picture is based principally on one of John Wells' more recent up-dates (unpublished). Generalized distribution maps for most Indopacific corals are to be found in Veron (1986), and for both. Indopacific and Atlantic corals in Wood (1983). Scheer (1984) and Sheppard (1987) give the most complete coral lists of Indian Ocean localities to date.

It is convenient to consider reef coral distributions firstly under spatial patterns, and then temporally (stratigraphically), mainly with respect to the Cainozoic. It is usual to divide spatial patterns into those related to latitude and those related to longitude. For Recent corals, the data are largely and unavoidably generic, and based on zooxanthellate forms. For extinct fossil corals, symbiosis with zooxanthellae is conjectural, so I follow general practice in using corals that can reasonably be supposed to have been symbiotic on palaeoecological, phylogenetic or morphological grounds (i.e. as implied in Wells, 1956). For fossil genera that are still extant however, it is reasonable to assume that they were also zooxanthellate. I use the broad term "reef corals" as short-hand for "extant zooxanthellates plus zooxanthellate-like extinct corals", because the correlation between zooxanthellate forms and reef-association is adequate for present purposes. Nevertheless, it should always be remembered that there are numerous corals that are neither reef-associated nor zooxanthellate (Wells, 1956; Rosen, 1981; Schuhmacher \& Zibrowius, 1985), and these are omitted from this account.

\section{Present-day latitudinal patterns}

The largest number of coral genera occurs more or less equatorially, but with a noticeable northerly deflection in the Caribbean (Figure 1; see also Stehli \& Wells, 1971). It declines steeply near, or just beyond, the tropical margins (Figure 2; see also Rosen, 1981). Wells (1954) stated that the same genera seem to drop out in the same order going from the lowest-latitude, highest-diversity areas to the margins of the reef coral belt, but later Stehli \& Wells (1971) investigated this using a ciuster analysis and found "minor differences" in drop-out sequences in different directions away from the diversity foci.

Latitudinal information about species is still insufficient, globally, to make useful generalizations. Veron (1986) found that around Australia, truly tropical coral faunas with a high diversity were "generally similar", but closer to the tropical margins, there were significant faunal differences. The relatively sudden decline in genera at or near the tropics (above), however, seems to be echoed at species level by Australian corals since Veron found that diversity along the reefs of eastern Australia remains high throughout the tropical belt until the Capricorn and Bunker reef groups are reached at the southern tropical limit of eastern Australian reefs. Sheppard's (1987) compilation and cluster 

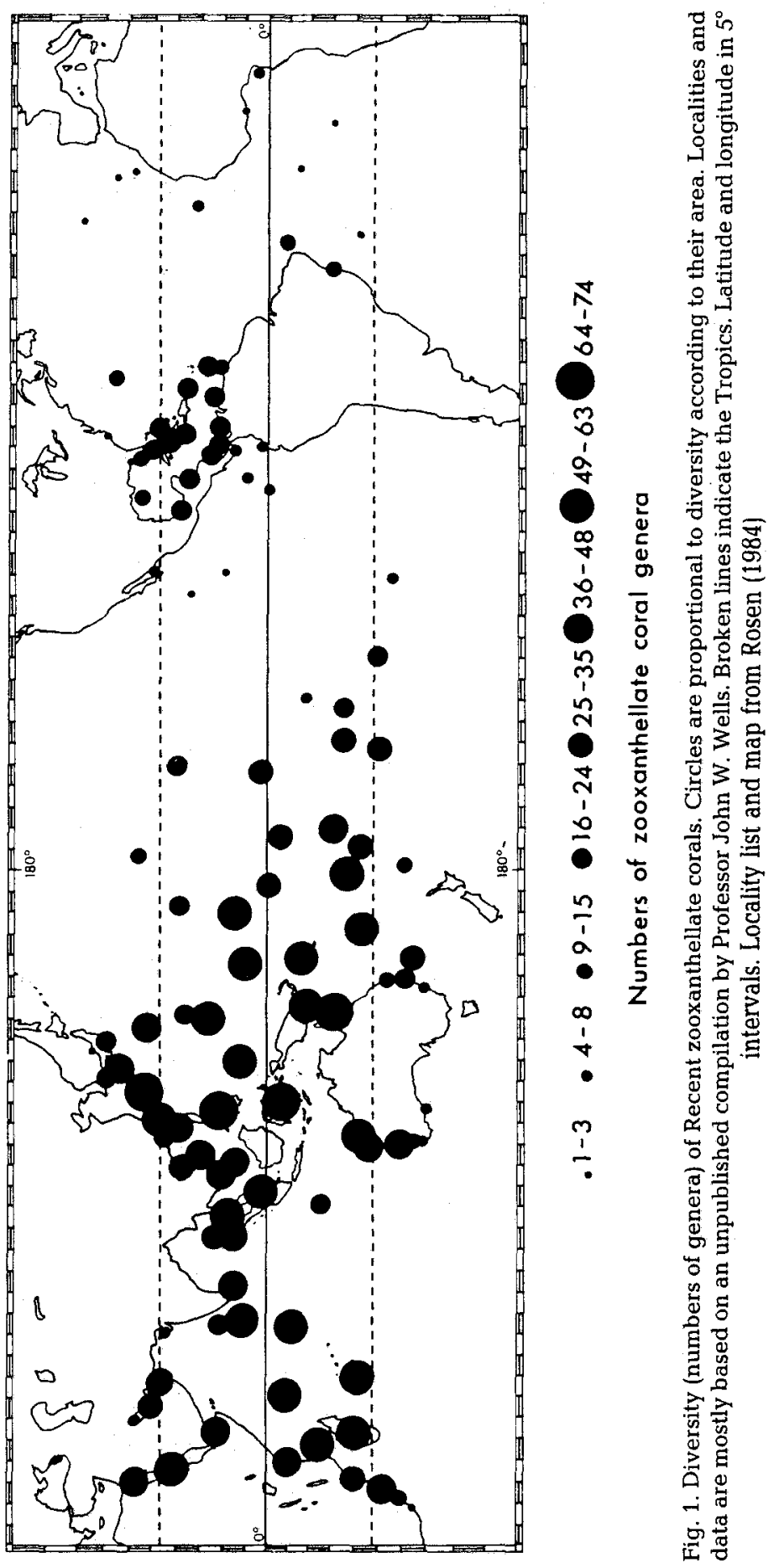
(o)
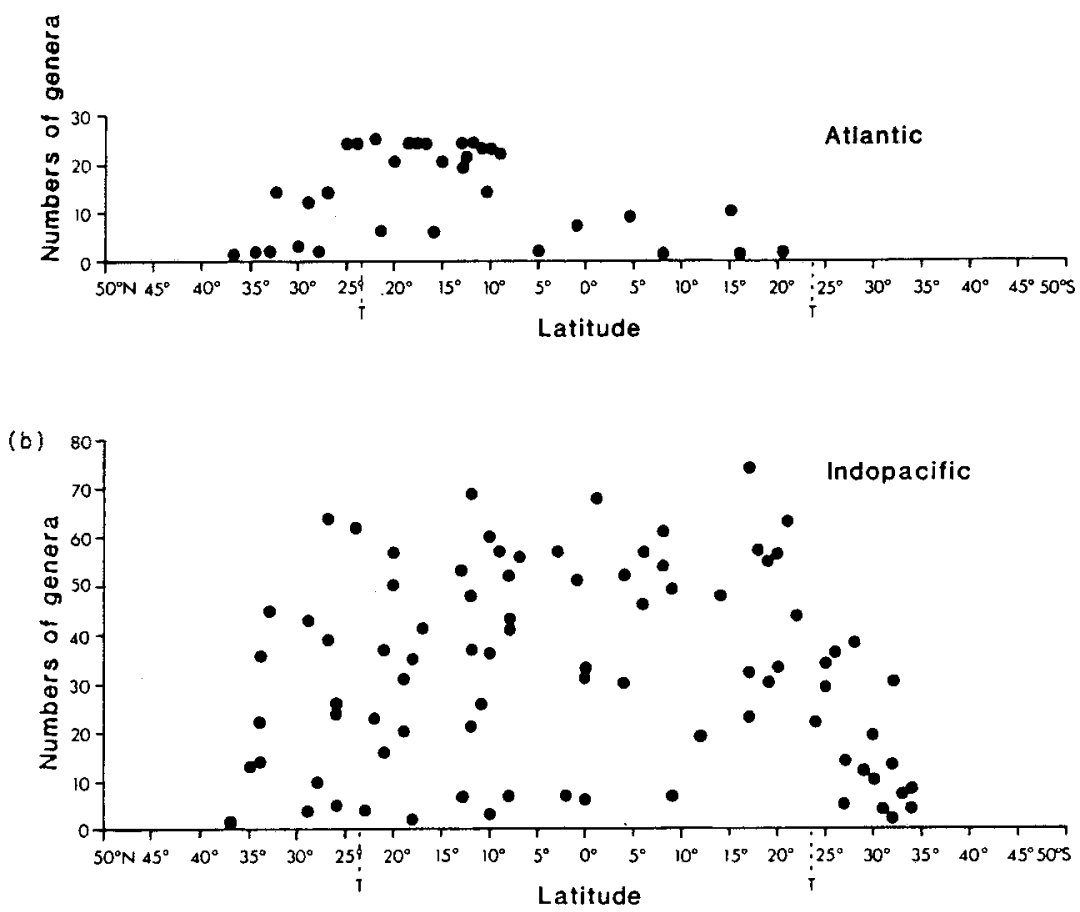

Fig. 2. Diversity (numbers of genera) of Recent zooxanthellate corals in relation to latitude: (a) Atlantic, (b) Indopacific. Data as in Fig. 1. Mid-point latitudes are used for localities with large areal extent. $\mathrm{T}=$ Tropics. Locality list and diagram from Rosen (1984)

analysis of 24 Indian Ocean localities differs from the usual latitudinal picture based on genera in several interesting respects. Highest species diversity is in the Red Sea and Western Australia, both of which areas are quite close to the latitudinal margins of the reef belt and also some distance from the western Indian Ocean proper. Sheppard also found patterns of local endemicity which appear to be strongest in a latitudinal direction, rather than longitudinally, the most important faunal divide being more or less along the equator.

\section{Present-day longitudinal patterns}

Numerous authors have drawn attention to the Indo-West Pacific high diversity region or "focus". The Caribbean also appears to be a focus in its own right within the Atlantic Ocean, though it is secondary in significance to the Indo-West Pacific one. The presence of a third focus in the western Indian Ocean has also been widely discussed, though as already mentioned, Sheppard (1987) found that the highest s pe cies diversity in this ocean region is actually in the Red Sea and Western Australia. The Carribean and Indo-West Pacific foci are defined longitudinally by strong gradients in diversity, declining eastward to fewer than five genera in both cases. In the eastern Indian Ocean the nature of the eastward decline is less clear, being based largely on the low diversities 
of just the small islands of Cocos Keeling and Christmas. The Indian Ocean shores of Indonesia are also rather low in diversity, but may reflect insufficient records, as Western Australia, not far to the south east, has a reef coral fauna as rich in some places as parts of the Great Barrier Reef (Veron, 1986).

Are the foci also characterized by endemic taxa? This does appear to be the case for both the Indo-West Pacific and Caribbean foci, which each have genera that do not occur elsewhere. Wells (1954) suggested that there was a definite drop-out sequence of genera along east-west gradients comparable to his latitudinal sequence (above), though as already mentioned, he later found that the latitudinal and longitudinal sequences are not quite the same. The converse of focal endemicity; peripheral endemicity, is relatively unusual, there being just a few genera that occur beyond, but not within, these two main foci (Wells, 1969; Rosen, 1984). By comparison with the two main foci, endemicity is very slight indeed within the supposed Indian Ocean focus, and there is also a limited amount of generic endemicity that is discordant with it (Wells, 1969; Rosen, 1971).

Underlying any discussion of reef coral distributions is the problem of range interpolation, since adult reef corals (in contrast to their pelagic larvae), are shallow water organisms and occur only where there are suitable features like carbonate platforms, islands and rocky coastlines. Since these are very discontinuous geographical features, reef coral distribution largely mirrors the distribution of suitable habitat areas. It is important therefore to distinguish the occurrence of low diversities in areas which otherwise seem to be environmentally suitable (e.g. the more easterly islands of the midand south Pacific: see figures given below) from low diversities that appear to reflect insufficiency or absence of suitable environmental conditions (e.g. the Persian Gulf). The implication is that the first may be a historical phenomenon and the second an ecological one.

To claim that the western Indian Ocean focus is a distinct feature implies that the first of these conditions in the area between the western Indian Ocean and the Indo-West Pacific (i.e. in the eastern Indian Ocean) are low in diversity in spite of suitable ecological conditions. Apart from Christmas Island and Cocos-Keeling however, the tropical eastern Indian Ocean is almost devoid of islands and shoals, so there is little on which to judge the issue. Long-term experimental work in the eastern Indian Ocean using larval settlement on buoys and plankton sampling, would seem to be the only way of acquiring more information. Jackson (1986) has summarized the results of this kind of work in the Pacific (see below).

Without this, the usual approach has been to interpolate records and diversities across the Indian Ocean. The criteria for doing this are arbitrary however (e.g. appendix in Rosen, 1984), and can give different results (e.g. see the different diversity "contour" maps in Rosen, 1971). Even the existence of identical species on either side of the eastern Indian Ocean is ambivalent, since we do not yet know whether populations of the same species on each side are in genetic exchange or not. The possibility of infraspecific disjunct populations cannot be overlooked. Further assumptions, based on ideas about foci also being centres of origin, only complicate the issue. Ideally, distributional maps of a particular taxon would also show or append actual locality records. For species, additional relevant information, if available, would include geographical information on transport of larvae and other life stages, and on genetic distances between sessile populations in different geographical areas. Lines drawn around known distribution 
limits and shaded patterns denoting overall geographical ranges of occurrence, together with diversity contours derived from such maps, would then at least be based on explicit biological criteria.

Similar considerations apply to the notable absence of many reef coral taxa in the eastern regions of both the Pacific and Atlantic Oceans, where there are also very few suitable habitat areas for reef corals. In contrast to the eastern shores of the Indian Ocean (e.g. Western Australia) however, where the reef coral faunas are very much richer than those of the few islands in the eastern ocean area itself, the faunas of the eastern shores of these other two oceans are very small. Diversity however is not always related to habitable areas in a simple way. In the Pacific Ocean it declines eastwards even within and between the archipelagoes of the mid- and south Pacific. For example, from west to east, the generic decline is: Great Barrier Reef 68, New Caledonia 59, Fiji 46, Samoa 41, Tahiti 34, Tuamotus 30, Marquesas 20 (data from Coudray \& Montaggioni, 1982; see also Wells, 1954). The basic pattern is probably not fundamentally altered by other more recent compilations for the individual areas, and is found in numerous other marine and terrestrial groups (Kay, 1980).

An important question has been, how far do these generic patterns also hold for species? Any answer to this is hindered by the notorious difficulty of applying reliable species names, especially when making compilations from the older literature. Rosen (1984) argued from the limited species evidence to date that there is much more regional endemicity than previously believed on generic grounds alone, and supposed that there was an overlapping mosaic of species ranges. As with latitudinal patterns of species, we have an insufficient picture, globally. Veron (1986) mentions regional endemicity around Australia. Sheppard's (1987) analysis of Indian Ocean localities has already been mentioned. Kay $(1980,1984)$ discusses the history of marine faunal subdivisions of the Pacific, which are presumably founded on observations of within-Pacific endemism in various marine groups including corals.

There are also some relevant theoretical grounds to consider in favour of considerable species endemism. Jackson \& Coates (1986) and Jackson (1986) emphasize that the life history pattern of reef corals favours the development of inbred and clonally distinct local geographical populations within a single species. On the other hand, they have also argued that corals are an exception because they are also capable of long-distance dispersion, if not as larvae, then especially during their sessile adult stage (e.g. by rafting), so the general implications for species distribution patterns is not clear from this. Potts (1983) has also argued in favour of regional subspecific inhomogeneity, attributing it to eustatically-driven "evolutionary disequilibrium", and emphasizing its contrast with "faunal homogeneity" at the species level.

It seems from the foregoing limited evidence however that faunal inhomogeneity exists or is to be expected at both subspecific and specific levels (though "homogeneity" would need to be quantified if this is to be investigated properly).

\section{Temporal patterns (mostly Cainozoic)}

Different accounts conflict considerably on the descriptive history of Cainozoic corals. It is also difficult to extract the relevant factual information about the stratigraphical record of corals because most accounts are also explanatory or interpretative. 
Typically, two kinds of process assumption are incorporated in these accounts: dispersal (sensu lato), and geological events as a direct cause of distributions (usually in the context of faunal provinces). There is also a strong emphasis on defining faunas and the affinities between them, though the way in which affinities are established varies from the informal and inexplicit to various non-standardized statistical methods.

Even the apparently simple and objective practice of naming faunas usually reflects some or all of these problems. In particular, it is common for palaeontologists to use names that reflect the supposed area of a biota's origin. For example, a biota first recognized at a particular horizon (T1) in a particular region $(A)$ is often referred to as the "A Biota". This in itself may seem reasonable, but when a similar, but not necessarily identical, biota is also recognized at a later horizon (T2) in another region (B), it is sometimes also referred to as the "A Biota" (rather than the more empirical "B Biota"). The reason for this seems to be because the younger biota is believed to consist largely of direct descendants of the A Biota, and the label denotes this supposed relationship. The underlying assumption is that of dispersal, often from a supposed centre of origin (in this case, region A), and clearly introduces bias into an apparently objective faunistic observation. Moreover, even the apparently innocent practice of defining a biota simply on its region of occurrence, without any such evolutionary assumptions, can also be misleading if that region is itself palaeogeographically hypothetical. The widespread usage of "Tethyan" for many Carboniferous to Cainozoic biotas illustrates both points. It is clear that a new, more empirical and consistent approach to the naming of biotas is needed, based ideally on the taxonomic elements of the biotas themselves (e.g. in the same way that biostratigraphers name their assemblage zones).

This section concentrates as far as possible on the stratigraphical record itself, and only the broadest patterns of faunal affinity. More interpretative accounts are treated as hypotheses in later sections. Unfortunately, the state of Cainozoic coral taxonomy, even at generic level, probably also obscures some of our knowledge of the stratigraphical record, as does the lack of a comprehensive up-date of the age of the various coralbearing horizons. The general consensus about the history of reef coral biotas (drawn mainly from Gerth, 1925, 1930; Yonge, 1940; Vaughan \& Wells, 1943; Wells, 1956; Newell, 1971; Chevalier, 1977; Frost, 1977a, b; Schafersman \& Frost, 1979; Coudray \& Montaggioni, 1982) is as follows.

The Palaeocene and Eocene sees a transition from Mesozoic to modern forms, there being an overlap between them during this time. Some of the modern families had emerged in the late Cretaceous, and almost all had appeared by the end of the Eocene. In general, during the Palaeogene, diversity was greatest in the Atlantic and Caribbean region, with rich faunas also in the Mediterranean.

Some authors emphasize the cosmopolitan nature of distributions during the late Cretaceous and early Tertiary (e.g. McCoy \& Heck, 1976; Frost, 1977a). Wells (1956), however, mentioned that differentiation of eastern Tethys biotas from those of what is now the Mediterranean and southern Europe was already evident in the Palaeogene. This was also pointed out by Gerth $(1925,1930)$ and by Coudray \& Montaggioni (1982). Rosen \& Smith (1988) showed that a similar pattern exists for sea urchins.

Coudray \& Montaggioni (1982) also indicate that the eastern and western Indian Ocean were also differentiated from each other during the Eocene, and Kay (1984) notes that the Indian Ocean, west Pacific and Pacific basin developed as separate biotas after 
the Eocene. Coudray \& Montaggioni (1982) state that the Pacific Ocean itself was probably uniform, faunally, from the Cretaceous through to the Eocene. For the Oligocene, Frost (1977a) also notes various species differences between the Caribbean/ Gulf of Mexico and Western Tethys [ = modern Mediterranean/Southern Europe]. Poddubiuk \& Rose (1986) found the same in echinoids during the late Oligocene and early Miocene. As with the question of Recent homogeneity of faunas, already mentioned, quantification and analysis is really needed in order to resolve or clarify many of these counter statements of cosmopolitanism and area affinities between faunas.

Around the Oligocene-Miocene boundary there were major extinctions amongst reef corals, according to Frost (1977b), who also noted the emergence of a "transitional fauna" in the early Miocene of the Caribbean. A distinctive fauna, not necessarily the same as Frost's fauna, nor necessarily the same everywhere, also seems to have existed globally at this time (own unpublished compilations). Differentiation of coral faunas into the two principal modern faunas of the Atlantic and Indopacific is often thought to have taken place during the Miocene, though there are certainly earlier signs of differentiation between the Indian and Atlantic Oceans, as already mentioned. During the Neogene, however, this differentiation becomes very marked. The modern Indopacific fauna emerged in the Miocene (Coudray \& Montaggioni, 1982), but not simply in the usual sense that the Atlantic had become physically separate from the Indopacific. Rosen \& Smith's (1988) faunal analyses suggest that within the Indopacific, the faunas of the Pacific Ocean, and of eastern Tethys plus the Indian Ocean, had remained distinct until this time, but "converged" (in the faunal sense) at some time after the early Miocene.

Diversity declined during the Neogene in the Atlantic/Caribbean and rose in the Indopacific, while in the Mediterranean, reef corals disappeared completely by the end of the Miocene, though some of its modern coral fauna is actually zooxanthellate (Schuhmacher \& Zibrowius, 1985). Table 2 shows this diversity history. Although numbers of genera declined in the Atlantic/Caribbean during this time, there were continuing speciations there (Frost, 1977b; Foster, 1988), but these new species have nearly all been placed within pre-existing genera. Rosen (1984) emphasised that the shift in diversity

Table 2. Regional and global numbers of reef coral genera from Oligocene to present, based on unpublished compilations from numerous sources. Finer stratigraphical division of Oligocene data was not possible for all regions. Note the change through time of the regions with the highest number of genera shown in bold. The Pliocene to Recent record of 2 genera in the Mediterranean region is based on non-reef-building zooxanthellates (see text). " no data available; + this figure is probably higher, to judge from preliminary examinations of new collections from Oman

\begin{tabular}{|c|c|c|c|c|c|}
\hline \multirow[t]{2}{*}{ Geological age } & \multicolumn{4}{|c|}{ Regional numbers of genera } & \multirow{2}{*}{$\begin{array}{c}\text { Global } \\
\text { number } \\
\text { of genera }\end{array}$} \\
\hline & $\begin{array}{l}\text { Caribbean - } \\
\text { W. Atlantic } \\
\text { Ocean }\end{array}$ & $\begin{array}{c}\text { Mediterranean - } \\
\text { W. Tethys }\end{array}$ & $\begin{array}{l}\text { S. W. Asia - } \\
\text { E. Tethys }\end{array}$ & $\begin{array}{c}\text { Indonesia } \\
\& \\
\text { Pacific Ocean }\end{array}$ & \\
\hline Recent only & 26 & 2 & 87 & 81 & 111 \\
\hline Pliocene-Recent & 33 & 2 & 88 & 95 & 124 \\
\hline Late Miocene & 28 & 7 & • & 59 & 76 \\
\hline Mid-Miocene & 28 & 32 & 30 & 49 & 79 \\
\hline Early Miocene & 41 & 44 & 53 & 58 & 90 \\
\hline Oligocene & 37 & 56 & $12+$ & 14 & 74 \\
\hline
\end{tabular}


"focus" to the Indo-West Pacific was due not simply to Atlantic extinctions, but to a significant surge in originations, with many new genera appearing, from the mid- to late Miocene onwards, a fact also noted with reservations by Umbgrove (1946). Kohn (1985) showed that a similar surge occurred in the diverse and largely tropical, predatory gastropods genus, Conus. Diversity also declined in the eastern part of the mid-Pacific during the late Neogene to present. Umbgrove (1946) also found evidence that originations increased again, at least in the Indonesian region, during the Pleistocene, though as he explained, this may have been the result of a sampling problem. This possible Pleistocene surge is directly opposite to Potts' $(1983,1985$; see Table 3) ideas about species stasis in the Pleistocene.

Throughout much of the Tertiary, the reef coral belt appears to have been latitudinally wider than it is today (Gerth, 1925, 1930; Wells, 1969; Newell, 1971; Adams et al., 1989), though it was noticeably narrowed to something like its present limits by the late Neogene, and was reduced still further during the Pleistocene when it was narrower than today (Stoddart, 1973).

Recent corals appear to be exceptional in showing strong biotic differentiation across the Isthmus of Panamà. For many of the other groups of organisms that occur along the shores of the eastern Pacific and amongst the nearest oceanic islands like Galàpagos, greatest biotic affinity is with the Americas and the Caribbean, their principal zone of biotic differentiation being the open ocean region of the eastern Pacific rather than the Isthmus (Berry, 1984; Rosen \& Smith, 1988). As many authors have pointed out, however, this pattern does appear to have applied to reef corals during the Miocene and Pliocene.

\section{IDEAS ABOUT THE ORIGIN OF MODERN REEF CORAL DISTRIBUTIONS}

\section{Background}

Explanations for distributions can be grouped according to the main process headings (above; and Table 1) of maintenance, distributional change and origination. For reef corals, ideas about distributional change and originations are essentially historical, and individual explanations usually include reference to both processes. There are at least thirteen such ideas and these are treated here under a combined heading, and summarized in Table 3.

The history of ideas about the origin of reef coral distributions very much reflects that of biogeography as a whole, except that there is still no published attempt to analyse their distributions using more recent methods, particularly cladistic biogeography (Humphries \& Parenti, 1986).

Early emphasis was on ecological influences, especially larval distribution and latitude control. Recent ecological ideas about reef coral biogeography reflect current interest in larval ecology and life histories (e.g. Valentine \& Jablonski, 1982; Jackson et al., 1985; Jackson \& Coates, 1986; Jackson, 1986). Although empirical investigation of environmental controls like temperature and latitude continues (Rosen, 1984), sufficient relevant ecophysiological knowledge is lacking. Valentine (1984a) has discussed this problem for invertebrates in general.

Earlier historical biogeographical theories (Table 3) developed around the classic idea of a centre of origin, usually thought to be the Indo-West Pacific focus (e.g. Stehli \& 
Wells, 1971), though other centres and dispersalist models have been added by various authors, sometimes linked with particular geological or oceanographical events (e.g. Frost, 1977b; Schafersman \& Frost, 1979). Challenge to the idea that taxa have originated in the focal regions seems to have been first made (for reef corals at least) by Ladd (1960). More recently there has been interest in the role of vicariance and refuges, some authors seeing the foci as areas of vicariance (e.g. McManus, 1985), and others (e.g. Rotondo et al. 1981) introducing vicariance and plate tectonics into Ladd's model of Pacific plate originations. Most Pacific plate theories usually also envisage that the Indo-West Pacific focus has been an area of species accumulation - in sharp contrast to its widespread acceptance as a centre of origin - whether by dispersal (Ladd, 1960) or in response to geotectonic and/or eustatic events (e.g. Rosen \& Smith, 1988). All these ideas address distributions on a large geographical scale. More regional in scale, there has also been considerable interest in two other problems: Hawaiian endemicity (e.g. Kay, 1984; Newman, 1986) and the origin of the east Pacific coral fauna (e.g. Heck \& McCoy, 1978). These are mentioned later only in their broader context.

\section{Maintenance theories}

\section{Latitudinal distributions}

The consensus view is that temperature is the key controlling factor of latitudinal distributions, both for the absolute geographical limits of reef coral distributions at the sea surface, and for the latitudinal gradients within the reef coral belt. Interestingly, this consensus is empirically based, lacking as yet ecophysiological tests. For example, there is a good empirical relationship between minimum annual sea surface temperatures of numerous regions, and their reef coral diversity, though many other regions show a diversity shortfall when compared with this temperature relationship (Figure 3). This is probably due to several different factors, such as incomplete sampling, regional habitat conditions, longitude-related maintenance factors, and historical factors. A large annual

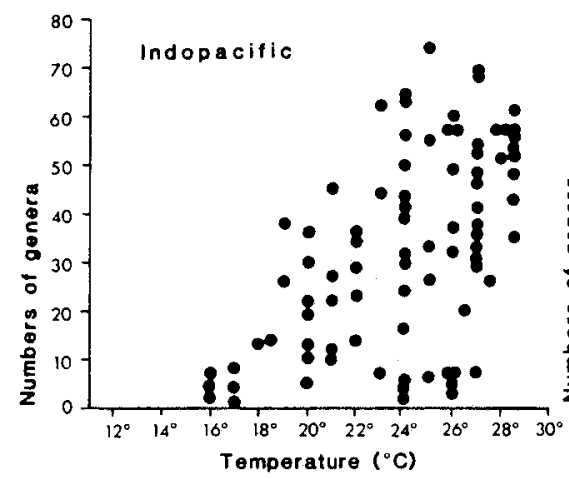

(a)

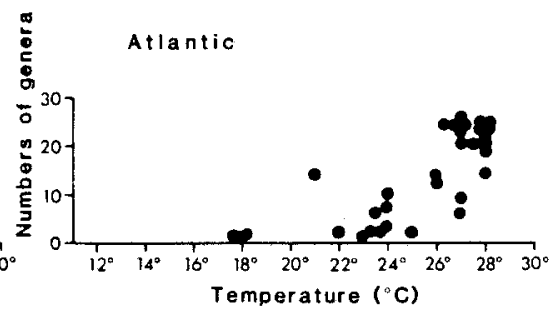

(b)

Fig. 3. Diversity (numbers of genera) of Recent zooxanthellate corals in relation to mean annual sea surface temperatures: (a) Atlantic, (b) Indopacific. Diversity and locality data as in Fig. 1. Temperature data from Stehli \& Wells (1971). Locality list and diagram from Rosen (1984) 
temperature range may also be important, though it may prove difficult to separate this factor, as its geographical expression (i.e. within reef coral latitudes) broadly correlates with minimum temperatures.

\section{Longitudinal distributions}

These have stimulated far more speculation and investigation than latitudinal distributions. In summary, it seems that the current consensus about longitudinal patterns is that they cannot readily be explained by maintenance processes alone, there being a strong historical element in their origin, even if there is as yet little agreement about what this history might have been (Table 3 ).

The first point to note is that longitudinal diversity gradients to the east of the focal regions show a much less marked relationship to temperature than do latitudinal gradients (e.g. see Wells' [1954] map of diversity and sea water temperatures). This suggests that some other kind of maintenance factors than temperature, or long-term historical factors, or a combination of both may be important. It is with respect to longitudinal patterns that coral biogeographers have differed from each other most, and where resolution of the alternatives still seems to be long way off.

The most usual explanation for longitudinal patterns has been a dispersalist one, based on the varying ability of different corals to traverse oceanic expanses between islands. The broader the expanse, the fewer corals there are that are supposed to be able to traverse it. This amounts to saying that longitudinal distributional patterns are a function of density of islands. This relationship is indeed a reasonable working generalization, and is the view most commonly found in the literature, though it has not been rigorously tested. It does not follow, however, that dispersal is actually the reason for this pattern. Island density is an important parameter in several distinct biogeographical processes (Rosen, 1984).

In any case, different authors actually conceive dispersal in different ways, and on different time scales, or otherwise do not state precisely what aspects of dispersal they envisage. In the present context of maintenance theories, it is dispersion that is relevant - the routine, "steady-state", short-term, distributional processes by which a species maintains gene flow throughout its observed existing geographical range. Hence, the question of "dispersal" and island density must be rephrased in terms of two possibilities: dispersion, or wholesale distributional change by various possible processes, mostly historical (Table 1). These are now considered in turn.

(1) Dispersion. For corals this has always been thought to be a function of larval biology (e.g. Veron, 1985) and it has therefore been reasonable to assume that those coral species that have geographical ranges which extend across the widest uninhabitable areas, like deep water, are those whose larvae are capable of surviving longest in the plankton (Veron, 1985). This is apparently not so. Wells (1969) and Jackson et al. (1985) have mentioned the possibility that "dispersal" is not confined to larval stages, since rafting of adult corals may occur. Jackson (1986) considered this in more detail in his interesting review of larval biogeography in clonal benthic marine invertebrates, including corals, and showed that this, and various other non-larval ("sessile") modes of "dispersal", are quite common. Indeed coral larvae and larval settling are virtually unrecorded from open water experiments designed to investigate this, so he concludes that scattered distributions are more likely to be due to sessile "dispersal": "Rafting is the only reasonable explanation for the existence of the vast majority of clonal species [e.g. 
corals] on Indo-Pacific oceanic islands, and the most likely mode of dispersal between far closer localities such as Caribbean islands as well" (Jackson, 1986, p. 593). However, direct observations of oceanic plankton by R. Richmond (University of Guam) reveal that larval dispersion in corals is of much greater importance than Jackson claims, even with respect to long distances (pers. comm.).

Jackson's conclusion implies that sessile "dispersal" is frequent enough to be a mode of dispersion, but, taking Richmond's work into account also, observed distribution patterns are evidently a function of both larval and sessile dispersion. But can all reef coral distributions really be explained by "dispersal", even species that range from the Red Sea to the mid-Pacific? If so, the following predictions and implications would apply. Firstly, apparently scattered populations of widespread species must either be in genetic exchange with each other by dispersal-sensu-dispersion, or, if they are not, they must be disjunct at an infraspecific level. Disjunction is usually regarded as a historical phenomenon for which there are two classically opposed ideas (see Table 1): chance dispersal events that found new populations beyond the pre-existing range of a species ("jump dispersal"), or some kind of vicariant disruption of a pre-existing range.

Secondly, and if there are no grounds for infraspecific disjunctions, it predicts (or, more strictly, "retrodicts") that either all species are still found exactly where they were when they first came into existence (i.e. taking "dispersal" as synonymous with dispersion); or that long-term $\mathrm{ch}$ a $\mathrm{ng}$ es in distribution through time are achieved essentially through the same processes of dispersion (perhaps in the form of "jump-dispersal", as before). One way to tackle these possibilities would be through further investigation of the possibility of infraspecific, geographical populations (see for example Jackson \& Coates, 1986; Potts, 1983), particularly with a view to discovering the extent of occurrence of infraspecific disjunctions, and especially in widespread species.

(2) Long-term "dispersal". It is particularly the question of "long-distance dispersal" in reef corals and other organisms, as challenged for example by McCoy \& Heck (1976) and Heck \& McCoy (1978), that highlights confusion in dispersalist explanations for distributions. There is a clear difference between (1) a widespread distribution of a species which is being maintained by current population processes (dispersion) even over great distances, and (2) a widely scattered distribution that is the result of a wholesale change or disjunction in the past of its entire population continuum, whether by chance events or by any other long-term process of distributional change. Newell (1971) recognized this distinction. Conceptually, dispersion processes and processes of distributional change do not preclude each other. The difference is partly also a matter of time scales - an example of different levels within the biogeographical system. (This distinction between dispersion and distributional change seems to be difficult to grasp, so an analogy with the physical behaviour of gases might be helpful. Dispersion theories are comparable with kinetic theories of gas molecules. Processes of distributional change are analogous to what happens to gases when, for example, the valves of containing systems and vessels are opened and closed, or whole containers moved around.)

It follows that neither the evidence for long-distance dispersion, either at larval stages (Veron, 1985; Richmond, pers. comm.) or sessile stages (Jackson, 1986), nor that against it (e.g. McCoy \& Heck, 1976; Heck \& McCoy, 1978) throws clear light on whether widespread species distributions (such as in the often cited case of the coral fauna of the eastern Pacific) are exclusively due to these processes. In fact, it is interesting that 
Jackson (1986) and McCoy \& Heck appear to be in agreement that long-distance larval dispersion in reef corals is not particularly common or biogeographically important. But whereas Heck and McCoy believe that this is true of all long-distance dispersion, Jackson argues that it is important nonetheless at the se s sil e stage.

The question of whether long-distance jump-dispersal occurs, or if it does, whether it is biogeographically significant is a different issue again. As a theory it has been widely criticised (e.g., for Pacific marine biotas, Rotondo et al., 1981). Historical theories based on faunas changing their distributions in passive response to geographical changes in environmental conditions and tectonic events are currently preferred by many authors (see next section). As it happens, long-distance dispersio n is not necessarily incompatible with, nor therefore a test of, any of these theories of distributional change, including jump dispersal.

Eastern Pacific. As the historical alternatives of explaining the trans-eastern Pacific coral fauna have been broached, it is appropriate to make some concluding remarks here, rather than later under historical headings. Even if the widespread transeastern Pacific pattern in modern reef corals is currently being maintained by longdistance dispersion, of whatever kind, this would not necessarily explain how this pattern arose in the first place. If the fossil evidence is a reliable indication (and in the case of Pacific marine organisms, the record is frustratingly patchy), we know that it is only late Cainozoic in age (Heck \& McCoy, 1978), though the genera concerned are much older. Why should this pattern be so recent?

The common historical explanation is of course, long-distance jump-dispersal, but it is equally possible that it is the consequence of faunal convergence (Dana, 1975; Rosen \& Smith, 1988). For example, oceanographic or tectonic events in the late Cainozoic may have brought the eastern Pacific within the routine dispersion range of the particular Indopacific species now found there, enabling each of their respective geographical populations to extend themselves eastwards from the Pacific basin. [Stehli \& Wells' (1971) cluster analysis shows an affinity between Hawaii and the eastern Pacific.] Perhaps the species concerned are also included in those that Jackson (1986) believes show the greatest tendency for long-distance dispersion, but this is not essential to a convergence hypothesis. Such an explanation is certainly no less parsimonious or testable than Heck \& McCoy's (1978) hypothesis, based on late Cainozoic recolonization by short-distance "dispersal" from (unknown) offshore refuges; and both alternatives can be postulated as historical hypotheses in their own right, independently of whether or not long-distance dispersion is a real phenomenon.

Ecological conditions. Whatever modes of dispersion apply to reef corals, the occurrence of particular corals at particular places will clearly also depend on local environmental conditions. In fact, a considerable literature exists that attributes longitudinal patterns of distribution to regional and local ecological factors rather than to dispersion, though these are not necessarily alternatives. One can envisage that any distribution patterns that might otherwise have arisen through dispersion factors alone, whether through larval or sessile stages, are probably modified by the "carrying capacity" of particular areas. In the first place this is a function of local habitat conditions (e.g. substrate, productivity, salinity, grazing and predation), but more theoretically, ideas like habitat heterogeneity, area effect, species equilibrium and environmental stability have also been put forward. 
Rosen (1975) applied Valentine's (1973) general diversity model to reef corals. The high diversity foci of the Caribbean and the Indo-West Pacific were seen as a response to (1) a high degree of spatial heterogeneity both in the present habitat sense and through their well known tectonic instability through geological time, (2) their high climatic and oceanographical "stability" and (3) their "intermediate resource levels". All three characteristics however would serve only to explain why so many species are to be found in the foci today - not how they arrived there, how they originated, why the Atlantic and Indopacific have such different diversities (in the approximate ratio of 1:4 respectively; Figure 1), and nor why these oceans have had such different late Cainozoic faunal histories. Moreover, while habitat heterogeneity is an intuitively reasonable supposition for the focal regions, it shares with the idea of stability difficulty of testing, especially on a biogeographical scale.

In general, the literature treating many of the other more theoretical eyolutionary ecological ideas (above) also seems to be largely inconclusive with respect to reef coral biogeography (Rosen, 1981, 1984). On the other hand, the third parameter, resource levels, though it is more readily tested, does not seem to hold. Depending on exact interpretation of "resources", intermediate conditions are actually more typical of the open ocean regions of the tropics (e.g. the mid-Pacific) than the densely islanded areas of the Indo-West Pacific focus (Birkeland, 1984; Birkeland \& Grosenbaugh, 1985), and presumably also the Caribbean focus. In fact, since their earlier habitat-orientated models, Valentine and Rosen (and their respective co-workers) have evidently shifted in their approach, introducing historical factors (Valentine \& Jablonski, 1982; Valentine, 1984a, b; Rosen, 1984; Rosen \& Smith, 1988), as explained in the next section.

\section{Theories of origination and distributional change}

\section{Summary of principal ideas}

Very few ideas about the origin of coral distributions have actually been tested, and it is too early to say which of them represents the most robust hypothesis, there being so little hard evidence or real data analysis. Probably the most useful approach at the moment is the one adopted by Potts (1985) in his review of three recent ideas in particular, and to set out as many as possible of the main hypotheses as theoretical alternatives (Table 3 ), though these alternatives are not necessarily mutually exclusive.

The problem of distinguishing long-term ideas from short-term, maintenance ideas has already been discussed in connection with dispersal theories. In this section, "dispersal $^{\prime \prime}$ is understood in an entirely historical sense, and most broadly, it is synonymous with "distributional change" on a long-term time scale, as in Table 1. For some authors, it may also mean jump-dispersal in particular, though for others, the intended meaning is not at all clear. Distributional change here means the change in the distributional limits of the whole geographical population continuum of the taxon through time, whether the result is expansion, contraction (e.g. into refuges), disjunction or any other kind of regional adjustment.

In inferring distributional changes, two problems arising from the palaeogeographical frame of reference should be borne in mind. The first is that palaeogeography is, to a 
greater or lesser extent, hypothetical, so ideas about changes in a taxon's distribution have often had to be amended to fit in with new palaeogeographical hypotheses. The only satisfactory way of avoiding this is to depend on a palaeogeographical frame of reference as little as possible. This can be done by using only "sample areas" or "sample localities" defined as objectively as possible in terms of such features as present-day geological outcrops and formations, and modern place names (Rosen, 1988b). Palaeogeographical reconstructions can then be introduced for discussion or comparison, once the biotic data have been assembled and analysed. The second problem is that it is misleading to think of biotas moving with respect to a static network of areas. As areas themselves are (or may have been) in a continuous state of relative movement, there is likely to have been at least a component of distributional change that is completely passive. Australian terrestrial biotas, for example, may well have been confined to Australia for a long geological time, but they have nevertheless "moved" in the sense that their latitudinal reference has been changing as Australia moved northwards during the Cainozoic. (Even the apparently absolute reference framework of latitude and longitude is unsatisfactory if we accept the idea that the earth has appreciably changed in dimensions through geological time).

In general, historical biogeographical ideas are framed in terms of general theories of (1) distributional change and (2) originations (speciations and extinctions), qualified by reference to particular geological horizons and particular geographical or palaeoegeographical regions. Table 3 summarizes the principal ideas concerning reef coral distributions that have appeared in the literature mostly since 1970. It is envisaged here that the kinds of maintenance processes already discussed, are superimposed on one or more of these historical processes, and that collectively, maintenance theories are not necessarily alternatives to historical theories, but more probably complementary to them. In general it is useful, especially in theoretical discussions, to decouple them, though in reality they must all be integrated at different levels within the biogeographical system.

The range of ideas in Table 3 is perhaps surprising, but undoubtedly, it accurately reflects the recent history of contrast and controversy in biogeography as a whole. Very few of the theories adequately address all of the generalized facts summarized in the previous section, especially as there has been a tendency to concentrate on either the Atlantic or Pacific, with the Indian Ocean being relatively neglected. Some theories are couched in much more general geological or geographical terms than others, and some do not cover both originations and distributional change, though the possibility of distributional change should not be rigidly assumed. Representation of a particular idea in the table is not intended to suggest that it has been tested, or even that it is testable. The aim has been to compile, perhaps for the first time, a representative sample of the range of ideas that have been put forward in the study of reef coral biogeography for the main purpose of concentrating future work. Many of the theories have also been applied, or might well be applied, to other marine tropical organisms.

The theories are arranged as far as possible to show their main shared characteristics, as well as possible influences and developments. This should not be read too literally however, as two similar theories may have appeared independently of each other, and perhaps as a result of influence from biogeographical developments elsewhere. The main sequentially-arranged groupings are: Focal centres of origin: 1-3; Focal speciation by vicariant allopatry and focal accumulation: 4-5; Pacific basin originations by marginal 
Table 3. Thirteen historical theories for explaining the origin of Cainozoic to Recent distributions of reef corals. As far as possible the sequence is intended to reflect the importance and development of various key ideas, not necessarily by direct chronological influence or outright replacement of one theory by another - see text. (I-WP means Indo-West Pacific)

\begin{tabular}{|c|c|c|c|}
\hline \multirow[t]{2}{*}{ Author } & \multicolumn{3}{|c|}{ Hypotheses } \\
\hline & Speciations & Extinctions & Distributional change \\
\hline $\begin{array}{l}\text { (1) Stehli \& Wells } \\
\text { (1971); see also } \\
\text { Ekman } \\
(1935,1953)\end{array}$ & $\begin{array}{l}\text { I-WP centre of origin of } \\
\text { species at least since } \\
\text { Mesozoic } i \text { no particu- } \\
\text { lar pattern or theory } \\
\text { mentioned for rate or } \\
\text { timing of speciations }\end{array}$ & $\begin{array}{l}\text { no particular pattern or } \\
\text { theory mentioned }\end{array}$ & $\begin{array}{l}\text { taxa spread outwards } \\
\text { from focus by adapting } \\
\text { to less favourable con- } \\
\text { ditions in marginal re- } \\
\text { gions }\end{array}$ \\
\hline $\begin{array}{l}\text { (2) Valentine } \\
(1984 a, b)\end{array}$ & $\begin{array}{l}\text { 'double diversity } \\
\text { pump' (see text) for } \\
\text { latitudinal patterns } \\
\text { with Neogene specia- } \\
\text { tion surge in tropics as } \\
\text { they became warmer; } \\
\text { thermally driven vic- } \\
\text { ariance across equa- } \\
\text { torial regions }\end{array}$ & $\begin{array}{l}\text { no particular pattern or } \\
\text { theory mentioned }\end{array}$ & $\begin{array}{l}\text { taxa spread outwards } \\
\text { from focal regions as } \\
\text { tropics became warmer } \\
\text { in Neogene because } \\
\text { they were thermally } \\
\text { pre-adapted for doing } \\
\text { so }\end{array}$ \\
\hline $\begin{array}{l}\text { (3) Frost (1977b) } \\
\text { Schafersman \& } \\
\text { Frost (1979) }\end{array}$ & $\begin{array}{l}\text { I-WP and Caribbean } \\
\text { have been indepen- } \\
\text { dent centres of origin } \\
\text { of species especially } \\
\text { following Miocene dis- } \\
\text { ruption of Tethyan sea- } \\
\text { ways }\end{array}$ & $\begin{array}{l}\text { temporally concen- } \\
\text { trated in latest Oligo- } \\
\text { cene (no particular } \\
\text { theory); and in } \\
\text { Neogene of Med. and } \\
\text { Caribbean because of } \\
\text { oceanographical } \\
\text { changes and in Plio- } \\
\text { Pleistoc. because of } \\
\text { cooling and glacio- } \\
\text { eustasy }\end{array}$ & $\begin{array}{l}\text { distributions change in } \\
\text { response to geographi- } \\
\text { cal changes in environ- } \\
\text { mentally suitable con- } \\
\text { ditions; especially di- } \\
\text { vergence of biotas fol- } \\
\text { lowing geological and } \\
\text { oceanographical events } \\
\text { in Middle East and } \\
\text { Central America during } \\
\text { Neogene }\end{array}$ \\
\hline $\begin{array}{l}\text { (4) McCoy \& Heck } \\
\text { (1976) }\end{array}$ & $\begin{array}{l}\text { no particular regional } \\
\text { pattern, but speciation } \\
\text { favoured in areas of } \\
\text { many islands, e. g. to- } \\
\text { day, in modern diversi- } \\
\text { ty foci (I-WP. Carib- } \\
\text { bean) }\end{array}$ & $\begin{array}{l}\text { modern low diversity } \\
\text { areas due to extinc- } \\
\text { tions as continents } \\
\text { moved northwards du- } \\
\text { ring Cainozoic }\end{array}$ & $\begin{array}{l}\text { 'small-scale passive } \\
\text { range extensions' (not } \\
\text { 'long-distance disper- } \\
\text { sal') in response to tec- } \\
\text { tonic and climatic } \\
\text { events; net accumula- } \\
\text { tion in areas of many } \\
\text { islands, like foci (as } \\
\text { with speciations) }\end{array}$ \\
\hline $\begin{array}{l}\text { (5) McManus } \\
\text { (1985) }\end{array}$ & $\begin{array}{l}\text { regionally concen- } \\
\text { trated by vicariance } \\
\text { in present Indonesian } \\
\text { region when glacio- } \\
\text { eustatic low stillstands } \\
\text { turned this region into } \\
\text { a barrier across the } \\
\text { tropics during late } \\
\text { Cainozoic }\end{array}$ & $\begin{array}{l}\text { no particular pattern or } \\
\text { theory mentioned }\end{array}$ & $\begin{array}{l}\text { distributions change in } \\
\text { response to geographi- } \\
\text { cal changes in environ- } \\
\text { mentally suitable con- } \\
\text { ditions with intermix- } \\
\text { ing and sibling species } \\
\text { in I-WP focus when } \\
\text { high stillstands caused } \\
\text { breakdown of earlier } \\
\text { barriers in this region } \\
\text { (see speciations) }\end{array}$ \\
\hline
\end{tabular}


Table 3 (Continued)

\begin{tabular}{|c|c|c|c|}
\hline \multirow[t]{2}{*}{ Author } & \multirow[b]{2}{*}{ Speciations } & \multirow{2}{*}{$\begin{array}{l}\text { Hypotheses } \\
\text { Extinctions }\end{array}$} & \multirow{2}{*}{ Distributional change } \\
\hline & & & \\
\hline $\begin{array}{l}\text { (6) Ladd (1960), } \\
\text { Coudray \& } \\
\text { Montaggioni } \\
(1982)\end{array}$ & $\begin{array}{l}\text { in Cretaceous to } \\
\text { Palaeogene especially, } \\
\text { concentrated in mid- } \\
\text { Pacific islands because } \\
\text { conditions here most } \\
\text { suitable for allopatry } \\
\text { by fringe isolation }\end{array}$ & $\begin{array}{l}\text { major extinctions in } \\
\text { mid-Pacific as a result } \\
\text { of late Cainozoic } \\
\text { glacio-eustatic disturb- } \\
\text { ance }\end{array}$ & $\begin{array}{l}\text { oceanographically gen- } \\
\text { erated dispersal of of } \\
\text { mid-Pacific species to- } \\
\text { wards Indo-West Pacific } \\
\text { through Cainozoic; } \\
\text { elsewhere, distribution- } \\
\text { al change in response to } \\
\text { particular geological } \\
\text { events }\end{array}$ \\
\hline (7) Newell (1971) & $\begin{array}{l}\text { In general, fastest } \\
\text { evolution in tropics but } \\
\text { most likely sites of } \\
\text { speciation within } \\
\text { tropics are outer is- } \\
\text { lands of Pacific (as } \\
\text { Ladd, 1960) }\end{array}$ & $\begin{array}{l}\text { greatest in non-focal } \\
\text { regions; also climatic } \\
\text { factor in east Pacific } \\
\text { and Atlantic extinc- } \\
\text { tions during and since } \\
\text { Miocene }\end{array}$ & $\begin{array}{l}\text { long-distance larval dis- } \\
\text { persion maintains wide- } \\
\text { spread gene pools but } \\
\text { historically, distribu- } \\
\text { tions have changed by } \\
\text { species responding to } \\
\text { geographical changes } \\
\text { in environmental condi- } \\
\text { tions, hence focal re- } \\
\text { gions are refuges }\end{array}$ \\
\hline $\begin{array}{l}\text { (8) Rotondo et al. } \\
\text { (1981) }\end{array}$ & $\begin{array}{l}\text { As Ladd (1960) but } \\
\text { speciations explicitly } \\
\text { ascribed to vicariance } \\
\text { in Pacific islands } \\
\text { caused by geotectonic } \\
\text { events }\end{array}$ & $\begin{array}{l}\text { no particular pattern or } \\
\text { theory mentioned }\end{array}$ & $\begin{array}{l}\text { 'Island integration' hy- } \\
\text { pothesis: convergence } \\
\text { of island biotas through } \\
\text { geotectonic processes } \\
\text { (lateral plate motion) }\end{array}$ \\
\hline (9) Kay (1984) & $\begin{array}{l}\text { since Eocene, specia- } \\
\text { tion has proceeded in- } \\
\text { dependently on Pacific } \\
\text { plate, in W. Pacific and } \\
\text { in Indian Ocean; speci- } \\
\text { ation on Pacific plate, } \\
\text { as Ladd (1960) or poss- } \\
\text { ibly by vicariance (see } \\
\text { Rotondo et al., 1981) }\end{array}$ & $\begin{array}{l}\text { no particular pattern or } \\
\text { theory mentioned }\end{array}$ & as Ladd (1960) \\
\hline (10) Rosen (1984) & $\begin{array}{l}\text { regionally concentra- } \\
\text { ted by vicariance in } \\
\text { outlying islands of In- } \\
\text { dian and Pacific } \\
\text { Oceans due to geotec- } \\
\text { tonic events, but Neo- } \\
\text { gene speciation surge } \\
\text { due to vicariance } \\
\text { through glacio-eustatic } \\
\text { disruption of existing } \\
\text { inter-island population } \\
\text { patterns especially at } \\
\text { high stillstands; fewer } \\
\text { speciations in Atlantic } \\
\text { in Neogene because } \\
\text { too few scattered mid- } \\
\text { ocean islands there }\end{array}$ & $\begin{array}{l}\text { regionally concen- } \\
\text { trated in Atlantic and } \\
\text { Mediterranean due to } \\
\text { climatic cooling and } \\
\text { northward movement } \\
\text { of Tethyan seas during } \\
\text { Neogene }\end{array}$ & $\begin{array}{l}\text { as Frost (1977b) etc; but } \\
\text { also biotas 'driven' from } \\
\text { low-lying oceanic is- } \\
\text { lands at low stillstands } \\
\text { to high islands and con- } \\
\text { tinental margins of pre- } \\
\text { sent foci especially } \\
\text { since onset of glaciation } \\
\text { in late Cainozoic; hence } \\
\text { common occurrence of } \\
\text { sibling species in much } \\
\text { of Indopacific }\end{array}$ \\
\hline
\end{tabular}


Table 3 (Continued)

\begin{tabular}{|c|c|c|c|}
\hline \multirow[t]{2}{*}{ Author } & \multicolumn{3}{|c|}{ Hypotheses } \\
\hline & Speciations & Extinctions & Distributional change \\
\hline $\begin{array}{l}\text { (11) Rosen \& } \\
\text { Smith (1988) }\end{array}$ & as Rosen (1984) & as Rosen (1984) & $\begin{array}{l}\text { as Rosen (1984) plus hy- } \\
\text { pothesis that Indo- } \\
\text { pacific fauna is post- } \\
\text { early Miocene resulting } \\
\text { from faunal conver- } \\
\text { gence of Pacific and In- } \\
\text { dian Ocean faunas due } \\
\text { to northward movement } \\
\text { of Australia, associated } \\
\text { emergence of Indone- } \\
\text { sia, and also westward } \\
\text { movement of islands on } \\
\text { Pacific plate towards } \\
\text { same focal' region }\end{array}$ \\
\hline $\begin{array}{l}\text { (12) Potts (1983, } \\
\text { 1985) }\end{array}$ & $\begin{array}{l}\text { glacio-eustatic inhibi- } \\
\text { tion of speciation dur- } \\
\text { ing late Cainozoic be- } \\
\text { cause environmental } \\
\text { change too rapid in re- } \\
\text { lation to corals' very } \\
\text { long generation times; } \\
\text { no actual speciation } \\
\text { pattern or theory men- } \\
\text { tioned, but (by implica- } \\
\text { tion) occurs during } \\
\text { slow or absent eustatic } \\
\text { change, e.g. earlier in } \\
\text { Cainozic }\end{array}$ & $\begin{array}{l}\text { temporally concen- } \\
\text { trated at times of low } \\
\text { stillstands and region- } \\
\text { ally concentrated } \\
\text { amongst low-lying } \\
\text { oceanic islands }\end{array}$ & $\begin{array}{l}\text { temporally concen- } \\
\text { trated at times of eusta- } \\
\text { tic high stillstands; } \\
\text { long-distance dispersal } \\
\text { recolonization of remote } \\
\text { low islands previously } \\
\text { impoverished during } \\
\text { eustatic lows }\end{array}$ \\
\hline (13) Veron (1985) & $\begin{array}{l}\text { as Potts (1985) for late } \\
\text { Cainozoic glacio-eu- } \\
\text { static inhibition of } \\
\text { speciation; vicariance } \\
\text { and centres of origin } \\
\text { ruled out, but no alter- } \\
\text { native ideas about } \\
\text { speciation indicated }\end{array}$ & $\begin{array}{l}\text { no pattern or theory } \\
\text { mentioned }\end{array}$ & $\begin{array}{l}\text { importance of geologi- } \\
\text { cal disruption of Tethyan } \\
\text { seaways for modern In- } \\
\text { dopacific and Atlantic } \\
\text { biotas; but distributions } \\
\text { otherwise entirely due to } \\
\text { long distance larval 'dis- } \\
\text { persal' (i.e. ? disper- } \\
\text { sion, hence not histori- } \\
\text { cal at all) }\end{array}$ \\
\hline
\end{tabular}

isolation and allopatry: 6-7; Pacific basin originations by vicariant allopatry: $8-11$; Glacio-eustatic inhibition of speciation: 12-13.

Somewhat oblique in relation to these groups, there are also the following themes: Refuges and accumulation in focal regions: $4-11$; Vicariance: 5, 8-11; Influence of geographical changes in environmental conditions: 2-5, 7, 10-11; Possible significance of plate movements for "transporting" biotas: 8-9, 11; Possible significance of eustasy: 3,5 , $10-13$. 


\section{Further details of ideas summarized in Table 3}

Since a great deal of reduction of different authors' ideas was necessary in order to assemble Table 3, it is useful to append some further notes, as follows. The numbers below correspond to those in Table 3 . These notes also mention some similar ideas advanced for other marine organisms.

(1) Stehli \& Wells' (1971) hypothesis represents the application to reef corals of the long-standing idea of centres of origin.

(2) Valentine's (1984a, b) theory is an application of Shackleton's (1979) palaeoclimatic curves that show that latitudinal temperature gradients have become steeper since the start of the Neogene. Valentine's double-pump diversity hypothesis is a development of his much earlier latitudinal pump idea, in which he envisaged that climatic cooling in high latitudes in the Neogene led to adaptation and speciation in high latitude biotas. In addition he suggests that concomitant with this high latitude effect, climatic warming in the tropics had a vicariance effect on tropical biotas, splitting them more or less along the equator, and this was responsible for the late Cainozoic speciation surge in groups like reef corals. Valentine notes that a notable previous difficulty of the standard Indo-West Pacific centre of origin hypothesis (No. 1) is that species have to be conceived as spreading outwards (into the Pacific basin) against the prevailing direction of oceanographical currents. To overcome this, he proposed that taxa in the warmest areas (foci) were able to spread outwards into cooler areas as these became warmer, because they were already adapted to warmer conditions.

(3) In their study of Upper Oligocene to Middle Miocene echinoids of the Mediterranean and Caribbean, Poddubiuk \& Rose (1986) suggested that the Mediterranean was a centre for Atlantic distributions. This is in contrast with Frost's (and others') ideas, here, that the Caribbean was a centre. Gerth $(1925,1930)$ argued that isolation of the Caribbean during the Neogene was a significant cause of extinctions there and of its failure to recruit new taxa from elsewhere.

(4) McCoy \& Heck's (1976) paper is historically significant in its explicit challenge to the widespread acceptance of the idea of an Indo-West Pacific centre or origin for reef corals and other associated tropical marine organisms like mangroves and sea grasses. In fact, other alternatives already existed, notably those of Ladd $(1960$; no. 6), further discussed by Newell (1971), who postulated marginal speciation in the Pacific basin, with the Indo-West Pacific focus being a centre of accumulations. Although McCoy \& Heck challenged the centre of origin idea, they still suggested that the Indo-West Pacific (and Caribbean) was a principal area of speciations because, as island regions, they would have the highest probability for population isolation. The islands of the Pacific basin are more scattered than those of the focal regions, however, to isolation opportunities of the kind envisaged by McCoy \& Heck would presumably be much greater in the Pacific basin, and in this respect, Ladd's ideas actually constitute a more obvious challenge to the prevailing idea of focal centres of origin.

(5) McManus' (1985) ideas are actually based on tropical Mollusca, but are included here because of their general implications for tropical marine biotas (cf. Potts, 1985). His idea that Indonesia and adjacent islands have acted as a barrier and vicariance line has previously been suggested in a general way by Vermeij (1978), and discussed by Rosen (1984). 
(6) The undoubted influence of Ladd's (1960) ideas, developed primarily for Mollusca, but applied also to other groups like reef corals, has already been mentioned under no. 4 . Ladd, like Valentine (1984a; no. 2), drew attention to the problem that eastward "dispersal" across the Pacific from a supposed Indo-West Pacific centre was against prevailing ocean currents. Although the historical importance of ocean currents for distributional change can be debated (see section of maintenance theories), it is the idea of Pacific origins that is important and intriguing. Indeed, subsequent ideas like those of Coudray \& Montaggioni $(1982$; no. 6) and those listed under nos. 7-11 can be recognized as efforts, conscious or otherwise, to articulate Ladd's idea in more detail in the context of more recent biogeographical theory and newer knowledge of Pacific geology.

(8) Rotondo et al.'s (1981) paper is important for the detail of its ideas, and as with Ladd (1960), it has strong implications beyond Pacific basin biogeography. Since oceanic crust moves laterally and downwards through time, it provides a highly plausible mechanism for isolation and regional vicariance amongst the many islands that rise from the Pacific ocean floor. Moreover, since hot spots like Hawaii are relatively fixed in position, though islands themselves move with the plate on which they lie, lateral plate motion can also bring about convergence ("integration") and endemicity of island biotas. The general principle of convergence of oceanic islands must also apply to the way in which the mid-Pacific islands are generally moving towards the island arcs and continental masses of the Indo-West Pacific, and this has presumably been a process that has also been in action for some geological time (Rosen \& Smith, 1988; no. 11). As a general principle, the biotas of islands and many larger land masses have probably been subjected to this kind of geotectonic convergence (in addition to other processes) throughout the Phanerozoic (McKenna, 1973; Hallam, 1983; Rosen, 1983). McKenna (1973) referred to islands and land masses that have had, this biogeographical role, as "Noah's Arks".

Rowe (1985), in his discussion of the biogeography of various Pacific asteroids, followed Ladd's general ideas but adopted Rotondo et al.'s speciation ideas. Newman (1986) in a discussion of Pacific marine biogeography, and of Hawaiian endemism in particular, rejected Rotondo et al.'s (1981) ideas, preferring a hypothesis for the latter based on extinctions resulting from glacial cooling and glacio-eustasy. He points out that Hawaiian barnacles show both faunistic and taxonomic similarity to those of the high islands of the southeast Pacific, though neither kind of relationship has yet been shown for reef corals. Faunistic patterns in the Pacific are mentioned more particularly later.

(10) and (11) Rosen \& Smith (1988; no. 11) retained Rosen's (1984; no. 10) earlier idea that Cainozoic originations have been more numerous amongst the islands of the midPacific (and possibly mid-Indian Ocean) than in the Indo-West Pacific focus, attributing this to tectonics and also, for the late Cainozoic surge in particular, glacio-eustasy. For accumulation in the Indo-West Pacific focus, however, Rosen (1984) had suggested that glacio-eustatic events in particular had "driven" taxa towards this region, so completing the cycle of a glacio-eustatic "diversity pump".

So far, preliminary attempts to model this quantitatively (unpublished) require too many unwarranted assumptions especially about regionally selective extinctions, and Rosen \& Smith turned to geotectonic convergence to explain their inferred faunal convergence, rather than glacio-eustasy. In addition to westward movement of islands on the Pacific plate, they suggested that the northward movement of Australia towards Asia 
(and the central tropics) might also have been significant. Emergence, and hence great increase in the number and density of islands in what is now Indonesia and Papua New Guinea, presumably resulted from this collision event (approximately mid-Miocene). Not only would this have further increased the possibilities for convergence of biotas between the Indian and Pacific Oceans at this time, but also brought about convergence with southern tropical biotas around Australasia too (the possibility of pre-Miocene endemism of Australian marine biotas needs to be investigated in this context). Rosen \& Smith's faunal analyses show an apparent coincidence of timing of the emergence of the modern Indopacific biota (i.e. as an assemblage, not as individual taxa) with both these tectonic events as well as the onset of southern hemisphere glaciation. According to these theories, the Indo-West Pacific focus, far from being a centre of origin, seems to have been a grand triple-point biotic convergence. The collision of Australia however is now thought to be much earlier than Rosen \& Smith realized (see Discussion).

The possible importance of the northward movement of Australia has also previously been mentioned by Adams (1983) in his discussion of the biogeography of larger benthonic foraminifera - a group whose distribution has been remarkably similar to reef corals for much of the Cainozoic (Chaproniere, 1980). He suggested that this event facilitated east-west "dispersal" through the Indo-West Pacific. It is possible that the similar northward movement of India also influenced coral distributions (Coudray \& Montaggioni, 1982), but Adams (1983) found no evidence for this amongst larger foraminifera.

The possible pre-Neogene isolation of many Pacific basin areas finds complementary support in Schlanger's (1981; and Schlanger \& Premoli Silva, 1981) ideas about central mid-Pacific volcanism in Cretaceous times and subsequent foundering of the resulting land masses and archipelagoes in the late Cretaceous to Palaeogene (Rosen \& Smith 1988).

(12) Potts' $(1983,1985)$ ideas stand out as distinct from the general sequence and influence of ideas shown in the rest of Table 3 in their focus on population genetics. Note that speciations would presumably occur at times of sea level stability, or at least, times of only very gradual eustatic movement. This implies that speciations were more numerous before the onset of glaciation, and therefore must have ceased or declined since the start of the Pleistocene, and probably before, depending on when glaciation actually commenced (see for example discussion in Rosen, 1984). Distributions are thought to change according to a eustatically-driven ebb-and-flow model, expanding at low stillstands and contracting to focal region refuges at high still-stands. Umbgrove's (1946) conflicting inference of a Pleistocene speciation surge, has already been mentioned.

Pott's glacio-eustatic theory has been indirectly criticised by Jackson et al. (1985). The general proposition underlying Potts' theory is that corals, being predominantly clonal, rather than sexual in their reproduction, have such a slow turnover of sexually produced generations, hence slow genetic change, that they should be relatively more immune to natural selection by rapid environmental change than organisms that depend on sexual reproduction. Jackson et al. suggested that this should be reflected by significantly slower evolutionary rates, but in a comparative survey of geological longevities of clonal and nonclonal organisms from Triassic to Recent, they found no evidence of differences between the two groups. This does not rule out glacio-eustatic inhibition of speciation rates in corals, but suggests that, if it is true, some other reason is needed. 
(13) Veron (1985) adopted Potts' ideas above (no. 12) but whereas Potts did not explicitly put forward any particular mode and location of speciations, Veron categorically rejected both centres of origin and vicariance. The mode of speciation envisaged by advocates of centres of origin theories has never been made clear for reef corals, and could be sympatric or, as in McManus' theory (1985, no. 5), allopatric by vicariance in alternation with intermixing in the same region. Unless Veron was referring indirectly to an as yet unpublished new theory of speciation, the speciation mode he was presumably envisaging was allopatric speciation by marginal isolation. The most likely sites for this according to Ladd $(1960$; no. 6$)$ would seem to be the islands of the Pacific basin.

\section{Discussion}

With at least thirteen different historical explanations for reef coral distributions, it could never be said of coral biogeographers that they have difficulty in devising theories. It has been made clear however, especially by cladistic biogeographers, that the real challenge now lies in finding satisfactory methods for investigating biogeographical ideas. Even if the methods developed by cladistic biogeographers are not universally adopted or agreed, it is difficult not to recognize the general value of their having initiated and articulated this challenge. Turning to reef corals, however, where a truly investigative approach has scarcely yet begun, so there would seem to be little point in adding to existing reviews of theories for theories' sake. A considerable amount of such discussion based on compatability between theories, theoretical considerations 6 and problems of internal self-consistency can be found in most of the works cited in Table 3 and in the papers cited in the additional remarks on this table, especially those by McCoy \& Heck (1976), Kay (1980, 1984), Newell (1971), Rotondo et al. (1981), Rosen (1984), Rosen \& Smith (1988), Newman (1986) and Potts (1985)., For this reason, I concentrate discussion on those problems which have been investigated by pattern analysis of distributional data or other empirical approaches, or for which such investigation is possible. These investigations do not necessarily constitute rigorous tests in a hypothetico-deductive sense. Rigorous historical biogeography can also proceed inductively, by comparison of independently derived patterns (Rosen, 1988a).

(1) Major geological events of possible biogeographical sig$\mathrm{nificance}$ for reef corals. A review of all possible events of interest is beyond scope. Many of the works already cited mention or discuss particular major geological events because of their assumed role in influencing distributions, e.g. late Cainozoic onset of glaciation, Cretaceous uplift and volcanicity in the mid-Pacific, and northward movements of India and Australia. In fact, for the purposes of strict biogeographical analysis, documenting such events mainly serves to draw attention to a possible extrinsic influence on distributional history through its coincidental timing with a particular biotic event. The exact processes by which a geological event might influence distributions are largely speculative (notwithstanding their widespread acceptance), and even the idea of coincidental timing is open to the objection of unknown time lag between geological cause and biotic effect. For these reasons, geological and biotic events cannot reallyserve as strict tests for one another (Patterson, 1983; Rosen, 1988a).

Probably, the most important geological events from a modern coral point of view are those that seem to have led to differentiation of the main present-day endemic regions, Atlantic and Indopacific. This question also serves to illustrate the problem of testing. In 
the past, differentiation was often attributed to the emergence of the Isthmus of Panamà. Emergence is now widely regarded as a Pliocene event however, and as this long postdates faunal differentiation of reef corals [early Cainozoic according to Newell (1971)], it cannot have done more than accentuate or help to maintain a pre-existing pattern. In any case, on simple topological grounds, a continuous reef belt can only be differentiated into two segments if it is broken in tw o places, not one. This need not have occurred at the same geological time. The hypothesis for one of these breaks is that it lay in the region of the Americas, but since Panamà closure is too recent, the usual suggestion is that it was an oceanic barrier caused by the lack of islands and shoals in the eastern Pacific between the present islands of the central Pacific and those closer to the Americas. The usual hypothesis for the second break is that it lay between Africa-Eurasia and was due to the Tethyan Terminal Event (closure of Tethyan seaways by the emergence of land in what is now the Middle East). The exact dates of Tethys closure are not agreed upon however (Adams et al., 1983; Rögl \& Steininger, 1983, 1984; Steininger \& Rögl, 1984), and it seems likely that there were several closures and reopenings from the late Oligocene and earliest Miocene, with final closure perhaps as late as the mid-Miocene. As with Panamà however, it seems that closure was later than the advent of biotic differences across this region. This has been suggested by various authors including Gerth $(1925,1930)$ and Kay (1984) and is shown by Rosen \& Smith's (1988) analyses. As with McManus' (1985) patterns (see below), this does not mean that the biotic and geological theories are irreconcilable. Their apparent discrepancy might well be resolved with further analytical work.

Another apparent discrepancy arises from Rosen \& Smith's suggestion that the northward collision of Australia helped to bring about Indo-Pacific faunal convergence. The first collision of the Australian craton with terranes on the Pacific plate is late Oligocene (Pigram \& Davies, 1987), which is somewhat earlier than the inferred date of faunal convergence suggested by Rosen \& Smith's generic analyses (post Early Miocene). Perhaps there was a time-lag between tectonic events and their significant effect on the faunas (see also Chaproniere, 1980).

(2) A ge patterns. Stehli \& Wells (1971) drew attention to stratigraphical ages as a test of biogeographical theories, and demonstrated a pattern amongst living corals in which the youngest reef coral taxa were to be found (1) in the focal regions, and (2) more generally, in the Indopacific rather than the Atlantic. They pointed this out as evidence for an Indo-West Pacific centre of origin. The untestability of centres of origin theories has been widely discussed in the biogeographical literature, and cannot be treated here. The main difficulty is that even if one tries to define "primitive" rigorously, e.g. to mean geologically old, or on cladistic criteria, there remains the underlying problem that centre-favouring authors use conflicting kinds of distributional patterns as criteria for recognizing centres. McCoy \& Heck (1976) and Rosen (1984) have discussed some of these problems for reef corals, but Rosen also examined the raw data for age-and-area distribution of reef corals, arguing that much of the impressive focal gradient-like pattern obtained by Stehli \& Wells, was probably due to the Neogene origination surge in the Indopacific. Their use of averages and "age-contours" to produce maps probably resulted in smoothing out this surge. More recently, Newman (1986) has discussed the average age of reef corals and barnacles with particular regard to the history of the Hawaiian Islands fauna. 
(3) Speciation rates. Even though low diversity in the Caribbean compared with the Indopacific might be most readily attributed to climatic cooling and glaciation in the late Cainozoic, the sea water temperatures there today are not a great deal different from those in much of the Indopacific. On simplistic temperature grounds, therefore, the Caribbean should have shown a resurgence in diversity since the depletions of earlier climatic cooling. Why has this not happened? If there is a diversity-temperature equilibrium factor, the Caribbean might not have been warm long enough for full recovery, but as the Atlantic cannot recruit reef corals from the Indopacific (as far as we know), temperature cannot be the only factor. More likely this is a broader question of conditions within the Atlantic region. One interesting possibility that needs investigating is that conditions for speciation in the region have not been as favourable as in parts or all of the Indopacific (Rosen, 1984; no. 10 in Table 3). This might be investigated through studies of speciation rates (e.g. Foster, 1988) and genetic divergence (e.g. Potts, 1983).

(4) Faunal similarities. In the absence of comprehensive distributional data through geological time that would tell us more directly how distributions changed, and where and when new taxa appeared, we have to use indirect methods, Thus "facts" about past faunas are really hypotheses. Ideally, these have to be corroborated before we can go on to explain them in terms of biological and geological events and processes. Reference has already been made, for example, to the question of cosmopolitanism of reef coral biotas in the earlier Cainozoic and before. This might become clearer in due course as the relevant coral faunas are often rich and well known, but simply lacking modern comprehensive revision. The Pacific basin picture, however, will inevitably remain more obscure because its fossil record is so patchy. Tertiary formations of oceanic islands invariably lie hidden below the most recent deposits and, because such islands usually have a continuous subsidence history, they are often at considerable depth below sea level. Their investigation is mostly limited to bore hole sampling. Much of the older oceanic-region record of shallow water carbonates has been destroyed altogether through subduction.

Gerth's $(1925,1930)$ treatment of reef coral biotas is interesting because he departed from the usual area-of-origin practice of labelling biotas in that he adopted four areas as convenient units and then discussed (in a broadly quantitative way) how their relative similarity changed through time. Gerth's paper represents a pioneer effort to find patterns independently from assumptions or theories of process. Some of his broader patterns have already been mentioned in the section on temporal distribution patterns.

The similarity approach leads naturally to the more sophisticated statistical treatments of biotas, such as that by Stehli \& Wells (1971), itself a pioneer study using cluster analysis based on the Jaccard similarity coefficient. Although these authors used this method to investigate broad provincial differences in reef coral biotas, it is interesting to examine their results for the more detailed patterns between individual localities. Many of the minor groupings do not bear a very close comparison with present-day geography, so the implication is that the pattern produced by the method is at least in part historical. Stehli \& Wells used only Recent data, so Gerth's account $(1925,1930)$ remains the only one that provides a synoptic historical pattern of similarity in reef coral faunas through the Cainozoic.

Sheppard (1987) analysed Indian Ocean coral species by cluster analyses, and Veron (1986) showed a map of Australian species faunas divided into six regions on their 
similarities. Kay (1984) published analyses based on various tropical marine molluscan groups using the same method as Stehli \& Wells (1971), but these differ noticeably from Stehli \& Wells' coral results in that southeastern Polynesian coral localities cluster with all of Kay's other Pacific sites (Fiji, Guam, Marshalls, Ryukyus) rather than with Hawaii. Comparison of Sheppard's results with those of Stehli \& Wells is beyond scope here.

The value of these analyses and of comparisons between them is probably outweighed by the well known problems of similarity methods, amongst which the main one of interest here is that although they delineate areas or "provinces", there is no clear biogeographical meaning to these provinces, other than area classification for its own sake. In any case, different methods give different results. Do the areas they define reflect history, or ecological conditions, or both? Although they represent a useful step in the direction of analysis, there is no clear rationale for deriving biogeographical hypotheses from them (Rosen, 1988b).

(4) Parsimony analysis of endemicity. In an attempt to overcome similar problems, Rosen (1985) suggested that distributional data might be handled in the same way that characters are analysed in cladistics, namely parsimony analysis. In a sense, this follows on from biogeographers' earlier adoption of similarity methods used in numerical taxonomy in which geographical sample areas (OGU's: Crovello, 1981) were treated like taxa (OTU's), and their taxonomic elements treated like characters. The method itself, and the way in which it differs from cladistic biogeographical methods is more fully explained elsewhere (Rosen \& Smith, 1988; Rosen, 1988b; Goldman \& Rosen, unpubl.). Although there are still problems to resolve in the interpretation of PAE results, they do provide historical hypotheses about biotas as represented at the sample localities, in the form of area cladograms. While cladistic biogeography searches for area patterns with respect to originations, PAE searches for convergences and divergences of biotas through geological time. These patterns can in turn be used to generate geological hypotheses or to make comparisons with independently derived geological hypotheses.

Rosen \& Smith (1988) obtained results based on late Cretaceous and Eocene sea urchins, and on Early Miocene and Recent sea urchins and reef corals. The results they obtained have already been incorporated in the above summary of temporal patterns, and their ideas about the origin of the modern Indopacific biota (No. 11 in Table 3) are derived from their analyses. It is widely believed that reef corals also share a similar biogeographical history with mangroves and sea grasses (e.g. McCoy \& Heck, 1976), though ideas about the exact history of these groups seem to be as varied as those for reef corals. Preliminary results of work in progress on parsimony analysis of Recent mangroves and other organisms (Goldman \& Rosen, unpubl.) also fit with this idea of a shared history. In particular, the Indopacific mangrove flora, like the Indopacific reef coral and sea urchin fauna, seems to have emerged relatively recently in geological time. Presumably this occurred in the Miocene too, by extrapolation from Rosen \& Smith's (1988) analyses, but analysis of Miocene mangrove data would also be useful for corroboration. ("Flora" and "fauna" here mean, strictly, biogeographical assemblages.)

Rosen and Smith's analysis of Recent corals also shows some similarity of area groupings with those shown by Stehli \& Wells' (1971) cluster analysis, which gives support to the idea (above) that such cluster analyses probably also reflect, at least in part, historical events (for details, see Rosen, 1988b).

(5) Relationships. There are as yet few theories about biogeographical history 
of reefal organisms that are based on cladistic biogeographical analysis. The possibility of specific vicariance events, though discussed by various coral authors (see Table 3 ) still awaits cladistic investigation. An untested prediction that follows from Valentine's $(1984 a, b)$ hypothesis for example is that there should be patterns of amphitropical sister taxa of Neogene age.

The most extensive cladistic biogeographical studies that have been made for reefal organisms are probably those of Springer $(1981,1982)$ for Pacific shore fishes. One of his most consistent patterns was of possible vicariance on either side of the plate boundary of the western Pacific, perhaps connected with early Cainozoic isolation of Pacific plate islands from regions to the west (Rosen, 1984).

McManus (1985) has approached the question of vicariance within the Indo-West Pacific focus by reference to Croizatian "tracks" (see Humphries \& Parenti, 1986) of sister taxa. The problem with vicariance within the Indo-West Pacific focus has been discussed in some detail by Rosen (1984). In particular (and as pointed out by McManus), it is difficult to see where such a barrier or barriers would have lain, there being no clear indications from present submarine topography that a glacio-eustatic fall of the magnitude usually envisaged $(100-150 \mathrm{~m})$ would be sufficient to produce a complete land barrier across the Indopacific. Either (1) a barrier may have existed across the narrow seaways that still remained at times of low still-stands, caused by the existence of very unfavourable habitat conditions there, or, (2) the present-day sea floor topography between islands is a misleading guide to the palaeogeography of the region during such times. Certainly, geological change in the Indonesian region has been so rapid and recent that the second possibility seems reasonable. On the other hand, the further back in time one goes, the fewer and more scattered were the land masses that probably existed in what is now the Indonesian region (see earlier discussion of tectonic and biotic convergences in this region), and the lower the likelihood of them forming land barriers. Perhaps the vicariance barriers concerned were much older than McManus envisages, and due to open ocean and deep water that may have existed in this region during the early Cainozoic and earlier, before Australia moved northwards into the tropics.

Even so, McManus' patterns are interesting and are probably typical of many other tropical marine and reefal organisms. For reef corals however, "tracks" seem to be broader, many of them extending into the mid-Pacific on one side, and often also across the entire Indian Ocean even as far as the Red Sea on the other. In principle, and subject to further corroboration from such other organisms, McManus' patterns stand in their own right, regardless of whether a suitable geological theory has yet been found to explain them.

\section{CONCLUSIONS}

(1) There is a surprising amount of information in the fossil record of reef corals that has not yet been analysed probably because Cainozoic coral systematics has been neglected in more recent years.

(2) There have so far been too few rigorous empirical and experimental biogeographical studies to establish robust hypotheses about the origin of reef coral distributions, and the same appears to be true for many other reefal organisms. Vicariance amongst oceanic islands, early Cainozoic isolation of Pacific plate areas, and late 
Cainozoic convergence of Indopacific biotas brought about through plate movements currently have more empirical support than other historical theories.

(3) On the ecological side, hypotheses are obscured by ambiguity in the use of "dispersal" and its apparent confusion with dispersion. For dispersion hypotheses, it will be essential to continue investigations of regional population genetics, larval and reproductive biology, and frequency of sessile transportation of coral colonies. It should eventually be possible to establish a time base for dispersion in relation to supposed chance events and long-term changes in distribution. These kinds of studies in combination with further investigations of thermal ecophysiology will probably cast more light on maintenance factors.

(4) On the historical side, cladistic biogeographical analyses, further and more detailed parsimony analysis of endemicity extended to species level, and studies of possible regional differences in evolutionary rates are likely to be the most fruitful immediate directions of future studies.

Acknowledgements. I should like to thank Dr. A. Kay (University of Hawaii) for reading and commenting on the manuscript; Dr. R. Richmond (University of Guam Marine Station) for advice on larval biology of corals; and Dr. C. J. Pigram (Bureau of Mineral Resources, Canberra) for advice on the geotectonic history of Australia.

\section{LITERATURE CITED}

Adams, C. G, 1983. Speciation, phylogenesis, tectonism, climate and eustasy: factors in the evolution of Cenozoic larger foraminiferal bioprovinces. In: Evolution, time and space. the emergence of the biosphere. Ed. by R. W. Sims, J. H. Price \& P. E. S. Whalley. Acad. Press, London, 255-289.

Adams, C. G., Gentry, A. W. \& Whybrow, P. J., 1983. Dating the terminal Tethyan event. - Utrecht micropaleont. Bull. 30, 273-298.

Adams, C. G., Lee, D. E. \& Rosen, B. R., 1989. Conflicting evidence for tropical sea-surface temperatures during the Tertiary. (In press.)

Berry, R. J. (Ed.), 1984. [Galapagos issue]. - Biol. J. Linn. Soc. 21, 1-258.

Birkeland, C., 1984. Influence of topography of nearby land masses in combination with local water movement patterns on the nature of nearshore marine communities. - Unesco Rep. mar. Sci. 27, 16-31.

Birkeland, C. \& Grosenbaugh, D., 1985. Ecological interactions between tropical coastal ecosystems. A review of information for the South Pacific Regional Environmental Programme. - U.N. Environm. Rep. Stud. 73, 1-71.

Chaproniere, G. C. H., 1980. Influence of plate tectonics on the distribution of Late Paleogene to Early Neogene larger foraminiferids in the Australasian region. - Palaeogeogr. Palaeoclim. Palaeoecol. 31, 299-317.

Chevalier, J,-P., 1977. Aperçu sur la faune corallienne récifale du Néogène. - Mém. Bur. Rech. géol. minièr. 89, 359-366.

Coudray, J. \& Montaggioni, L., 1982. Coraux et récifs coralliens de la province indo-pacifique; répartition géographique et altitudinale en relation avec la tectonique globale. - Bull. Soc. géol. Fr. (Sér. 7) 24, 981-993.

Crovello, T. J., 1981. Quantitative biogeography: an overview. - Taxon 30, 563-575.

Dana, T. B., 1975. Development of contemporary Eastern Pacific coral reefs. - Mar. Biol. 33, 355-374.

Dauget, J.-M., 1986. Application des méthodes architecturales aux coraux, quelques traits communs aux formes vivantes fixées. Thèse, Univ. des Sciences et Techniques du Languedoc, Acad. de Montpellier, $245 \mathrm{pp}$.

Ekman, S., 1935. Tiergeographie des Meeres. Akad. Verl.-Ges., Leipzig, 542 pp.

Ekman, S., 1953. Zoogeography of the Sea. Sidgwick \& Jackson, London, 417 pp. 
Foster, A. B., 1988. Contrasting evolutionary patterns in reef-corals: an explanation based on life history and ecophenotypic plasticity. (In press.)

Frost, S. H., 1977 a. Oligocene reef coral biogeography Caribbean and western Tethys. - Mém. Bur. Rech. géol. minièr. $89,342-352$.

Frost, S. H., 1977b. Miocene to Holocene evolution of Caribbean reef-building corals. - Proc. 3rd int. Coral Reef Symp. 2, 353-359.

Gerth, H., 1925. Die Bedeutung der tertiären Riffkorallenfauna des malayischen Archipels für die Entwicklung der lebenden Riff-Fauna im indopazifischen und atlantischen Gebiet. - Verh. geolmijnb. Genoot. Ned. (Geol. Ser.) 8, 173-196.

Gerth, H., 1930. The evolution of reef-corals during Cenozoic period. - Proc. 4th Pacif. Sci. Congr. $2 A, 333-350$.

Hallam, A., 1983. Plate tectonics and evolution. In: Evolution from molecules to men. Ed. by D. S. Bendall. Cambridge Univ. Press, Cambridge, 367-386.

Heck, K. L., Jr. \& McCoy, E. D., 1978. Long-distance dispersal and the reef-building corals of the eastern Pacific. - Mar. Biol. 48, 349-356.

Humphries, C. J. \& Parenti, L. R., 1986. Cladistic biogeography. Clarendon Press, Oxford, $98 \mathrm{pp}$.

Jackson, J. B. C., 1986. Modes of dispersal of clonal benthic invertebrates: consequences for species' distributions and genetic structure of local populations. - Bull. mar. Sci. 39, 588-606.

Jackson, J. B. C. \& Coates, A. G., 1986. Life cycles and evolution of clonal (modular) animals. In: The growth and form of modular organisms. Ed. by J. L. Harper, B. R. Rosen \& J. White. The Royal Society, London, 7-22.

Jackson, J. B. C., Winston, J. E. \& Coates, A. G., 1985. Niche breadth, geographic range, and extinction of Caribbean reef-associated cheilostome Bryozoa and Scleractinia. - Proc. 5th int. Coral Reef Congr. 4, 151-158.

Kay, E. A., 1980. Little worlds of the Pacific. An essay on Pacific Basin biogeography. Univ. of Hawaii, Honolulu, 40 pp.

Kay, E. A., 1984. Patterns of speciation in the Indo-West Pacific. - Spec. Publs Bernice Pauahi Bishop Mus. 72, 15-31.

Kohn, A. J., 1985. Evolutionary ecology of Conus on Indo-Pacific reefs. - Proc. 5th int. Coral Reef Congr. 4, 139-144.

Ladd, H. S., 1960. Origin of the Pacific island molluscan fauna. - Am. J. Sci. 258 (A), $137-150$.

McCoy, E. D. \& Heck, K. L., Jr., 1976. Biogeography of corals, seagrasses and mangroves: an altemative to the center of origin concept. - Syst. Zool. 25, 201-210.

McKenna, M. C., 1973. Sweepstakes, filters, corridors, Noah's Arks and beached Viking funeral ships in palaeogeography. In: Implications of continental drift to the earth sciences. Ed. by D. H. Tarling \& S. K. Runcorn. Acad. Press, London, 1, 295-308.

McManus, J. W., 1985. Marine speciation, tectonics and sea-level changes in southeast Asia. - Proc. 5th int. Coral Reef Congr. 4, 133-138.

Newell, N. D., 1971. An outline history of tropical organic reefs. - Am. Mus. Novit. 2465, 1-37.

Newman, W. A., 1986. Origin of the Hawaiian marine fauna: dispersal and vicariance as indicated by barnacles and other organisms. In: Crustacean biogeography. Ed. by R. H. Gore \& K. L. Heck. Balkema, Rotterdam, 21-49.

Patterson, C., 1983. Aims and methods of biogeography. In: Evolution, time and space: the emergence of the biosphere. Ed. by R. W. Sims, J. H. Price P. E. S. Whalley. Acad. Press, London, $1-28$.

Pigram, C. J. \& Davies, H. L., 1987. Terranes and the accretion history of the New Guinea region. BMR Jl aust. Geol. Geophys. 10, 193-211.

Poddubiuk, R. H. \& Rose, E. P. F., 1986. Relationships between mid-Tertiary echinoid faunas from central Mediterranean and eastern Caribbean and their palaeobiogeographic significance. In: International Colloquium on Mediterranean Neogene marine megafaunal palaeoenvironments and biostratigraphy. - Annls géol. Pays hell. 32, 115-128.

Potts, D. C., 1983. Evolutionary disequilibrium among Indo-Pacific corals. - Bull. mar. Sci. 33, $619-632$.

Potts, D. C., 1985. Sea-level fluctuations and speciation in Scleractinia. - Proc. 5th int. Coral Reef Congr. 4, 127-132.

Rögl, F. \& Steininger, F. F., 1983. Vom Zerfall der Tethys zu Mediterran und Paratethys. Die neogene 
Paläogeographie und Palinspastik des zirkum-mediterranen Raumes. - Annln naturh. Mus. Wien 85 (A), 135-163.

Rögl, F. \& Steininger, F. F., 1984. Neogene Paratethys, Mediterranean and Indo-Pacific seaways. Implications for the paleobiogeography of marine and terrestrial biotas. In: Fossils and climate. Ed. by P. J. Brenchley. Wiley, Chichester, 171-200.

Rosen, B. R., 1971. The distribution of reef coral genera in the Indian Ocean. In: Regional variation in Indian Ocean coral reefs. Ed. by D. R. Stoddart \& C. M. Yonge. Acad. Press, London, 263-299.

Rosen, B. R., 1975. The distribution of reef corals. - Rep. Underwat. Ass. (N. S.) 1, 1-16.

Rosen, B. R., 1981. The tropical high diversity enigma - the corals'-eye view. In: Chance, change and challenge: the evolving biosphere. Ed. by P. H. Greenwood \& P. L. Forey. Cambridge Univ. Press, London, 103-129.

Rosen, B. R., 1983. Reef island staging posts and Noah's Arks. - Reef Encounter 1, 5-6.

Rosen, B. R., 1984. Reef coral biogeography and climate through the late Cainozoic: just islands in the sun or a critical pattern of islands? In: Fossils and climate. Ed. by. P. J. Brenchley. Wiley, Chichester, 201-262.

Rosen, B. R., 1985. Long-term geographical controls on regional diversity, - J. Open Univ. geol. Soc. 6 (2), 25-30.

Rosen, B. R., 1986. Modular growth and form of corals: a matter of metamers? In: The growth and form of modular organisms. Ed. by J. L. Harper, B. R. Rosen \& J. White. The Royal Society, London, 115-142.

Rosen, B. R., 1988a. Biogeographic patterns: a perceptual overview. In: Analytical biogeography. Ed. by A. A. Myers \& P. S. Giller. Chapman \& Hall, London, 23-55.

Rosen, B. R., 1988b. From fossils to earth history: applied historical biogeography In: Analytical biogeography. Ed. by A. A. Myers \& P. S. Giller. Chapman \& Hall, London, 437-481.

Rosen, B. R. \& Smith, A. B., 1988. Tectonics from fossils? Analysis of reef coral and sea urchin distributions from late Cretaceous to Recent, using a new method. In: Gondwana and Tethys. Ed. by M. G. Audley-Charles \& A. Hallam. Oxford Univ. Press, Oxford, 275-306.

Rotondo, G. M., Springer, V. G., Scott, G. A. J. \& Schlanger, S. O., 1981. Plate movement and island integration - a possible mechanism in the formation of endemic biotas, with special reference to the Hawaiian Islands. - Syst. Zool. 30, 12-21.

Rowe, F. W. E., 1985. Six new species of Asterodiscides A. M. Clark (Echinodermata, Asteroidea) with a discussion of the origin and distribution of the Asterodiscididae and other 'amphi-Pacific' echinoderms. - Bull. Mus. natn. Hist. nat., Paris (Sér. 4., Sect. A) 7 (3), 531-577.

Schafersman, S. D. \& Frost, S. H., 1979. Tropical Cenozoic paleo-oceanography and correlated events in phylogeny and biogeography of scleractinian corals. - Bull. Am. Ass. Petrol. Geol. 63, 521. (Abstract.)

Scheer, G., 1984. The distribution of reef corals in the Indian Ocean with a historical review of its investigation. - Deep Sea Res. 31 (A), 885-900.

Schlanger, S. O., 1981. Shallow water limestones in oceanic basins as tectonic and paleoceanographic indicators. - Spec. Publs Soc. econ. Paleont. miner. Tulsa 32, 209-226.

Schlanger, S. O. \& Premoli Silva, I., 1981. Tectonic, volcanic and paleogeographic implications of redeposited reef faunas of late Cretaceous and Tertiary age from the Nauru Basin and the Line Islands. - Initial Rep. Deep Sea Drilling Proj. 61, 817-827.

Schuhmacher, H. \& Zibrowius, H., 1985. What is hermatypic? A redefinition of ecological groups in corals and other organisms. - Coral Reefs 4, 1-9.

Shackleton, N. J., 1979. Evolution of the earth's climate during the Tertiary Era. In: Evolution of planetary atmospheres and climatology of the earth. Ed. by D. Gautier. Centre Nationale d'Etudes Spatiale, Toulouse, 49-58.

Sheppard, C. R. C., 1987. Coral species of the Indian Ocean and adjacent seas: a synonymized compilation and some regional distribution patterns. - Atoll Res. Bull. 307, 1-32.

Springer, V. G., 1981. Discussion (of A. Solem's paper). Comments on Solem's land-snail biogeography, with an hypothesized explanation of the distribution of the Endodentidae. In: Vicariance biogeography: a critique. Ed. by G. Nelson \& D. E. Rosen. Columbia Univ, Press, New York, $225-230$.

Springer, V. G., 1982. Pacific plate biogeography with special reference to shore fishes. - Smithson. Contrib. Zool. 367, 1-182. 
Stehli, F. G. \& Wells, J. W., 1971. Diversity and age patterns in hermatypic corals. - Syst. Zool. 20, 115-126.

Steininger, F. F. \& Rögl, F., 1984. Paleogeography and palinspastic reconstruction of the Neogene of the Mediterranean and Paratethys. In: The geological evolution of the eastern Mediterranean. Ed. by J. E. Dixon \& A. H. F. Robertson. Blackwell, Oxford, 659-668.

Stephenson, T. A. \& Stephenson, A., 1949. The universal features of zonation between tide marks on rocky coasts. - J. Ecol. 37, 289-305.

Stoddart, D. R. 1973. Coral reefs: the last two million years. - Geography 58, 313-323.

Taylor, J. D., 1968. Coral reef and associated invertebrate communities (mainly molluscan) around Mahé, Seychelles. - Phil. Trans. R. Soc. Lond. (B) 254, 129-206.

Umbgrove, J. H. F., 1946. Evolution of reef corals in East Indies since Miocene time. - Bull. Am. Ass. Petrol. Geol. 30, 23-31.

Valentine, J. W., 1973. Evolutionary paleoecology of the marine biosphere. Prentice-Hall, Englewood Cliffs, N. J., 511 pp.

Valentine, J. W., 1984a. Climate and evolution in the shallow sea. In: Fossils and climate. Ed. by P. J. Brenchley. Wiley, Chichester, 265-277.

Valentine, J. W., 1984b. Neogene marine climate trends: implications for biogeography and evolution of the shallow sea. - Geology 12,647-650,

Valentine, J. W. \& Jablonski, D., 1982. Major determinants of the biogeographic pattern of the shallow-sea fauna. - Bull. Soc. géol. Fr. (Sér. 7) 24, 893-899.

Vaughan, T. W. \& Wells, J. W., 1943. Revision of the suborders, families, and genera of the Scleractinia. - Spec. Pap. geol. Soc. Am. 44, 1-363.

Vermeij, G. J., 1978. Biogeography and adaptation: patterns of marine life. Harvard Univ. Press, Cambridge, Mass., $332 \mathrm{pp}$.

Veron, J. E. N., 1985. Aspects of the biogeography of hermatypic corals. - Proc. 5th int. Coral Reef Congr. 4, 83-88.

Veron, J. E. N., 1986. Corals of Australia and the Indo-Pacific. Angus \& Robertson, North Ryde, New South Wales, $644 \mathrm{pp}$.

Wells, J. W., 1954. Bikini and nearby atolls: (2) oceanography (biologic). Recent corals of the Marshall Islands. - Prof. Pap. U. S. geol. Surv. 260-I, 385-486,

Wells, J. W., 1956. Scleractinia. In: Treatise on invertebrate paleontology. Part F. Coelenterata. Ed. by R. C. Moore. Univ, of Kansas Press, Lawrence, Ks, F328-F444.

Wells, J. W., 1969. Aspects of Pacific coral reefs. - Micronesica 5, 317-322.

Wood, E. M., 1983. Reef corals of the world. Biology and field guide. T. F. H. Publs, Neptune City, N. J., 256 pp.

Yonge, C. M., 1940. The biology of reef-building corals. - Scient. Rep. Gt Barrier Reef Exped. 1, 353-391. 